\title{
Kansas Employment Law Survey
}

\author{
Elinor P. Schroeder \& Pamela V. Keller ${ }^{* *}$
}

\section{INTRODUCTION}

This Survey of Kansas employment law covers approximately the last five years. It focuses primarily on Kansas Supreme Court and Kansas Court of Appeals decisions, but it also includes some decisions of federal courts in Kansas applying Kansas law. Topics include the torts of retaliatory discharge, intentional infliction of emotional distress, and negligent hiring; implied and express contracts; noncompetition covenants and confidentiality agreements; arbitration agreements; and wage payment.

\section{RETALIATORY DischARGE}

\section{A. Firings Related to Exercise of Rights Under the Worker's Compensation Statute}

As all Kansas employment lawyers know, the first case in which the Kansas appellate courts recognized a cause of action for retaliatory discharge was Murphy v. City of Topeka, ${ }^{1}$ in which the Kansas Court of Appeals held that an employee who alleged he was fired because he had asserted a worker's compensation claim could sue his employer in tort. ${ }^{2}$ Although Murphy is now more than a quarter-century old, the worker's compensation arena remains an active one and has generated a number of interesting decisions. For instance, before the period covered by this Survey, Kansas courts had held that the cause of action extends to retaliation against the noninjured spouse of an employee who exercised his or her worker's compensation rights ${ }^{3}$ and to demotion, as opposed to

- Paul E. Wilson Professor of Law, University of Kansas School of Law.

* Clinical Associate Professor, University of Kansas School of Law. The authors appreciate the research assistance of Chris Steadham and Michael Breen.

1. 6 Kan. App. 2 d 488, 630 P.2d 186 (Kan. Ct. App. 1981).

2. Id. at 193 .

3. Marinhagen v. Boster, Inc., 17 Kan. App. 2d 532, 541, 840 P.2d 534, 541 (Kan. Ct. App. 1992). 
discharge, in retaliation for an employee's having filed a worker's compensation claim. ${ }^{4}$ The cases reviewed during the Survey period proved no different, both in the number of reported worker's compensation retaliation cases and in the issues they raised.

In Gonzalez-Centeno v. North Central Kansas Regional Juvenile Detention Facility ${ }^{5}$ the Kansas Supreme Court held that a cause of action for retaliatory discharge may exist against an employer other than the employer against whom the worker's compensation claim was or might be asserted. ${ }^{6}$ Gonzalez-Centeno worked for two unrelated employers, Venator and the North Central Kansas Regional Juvenile Detention Facility (NCKRJDF). ${ }^{7}$ He injured his back while on the job at Venator, and he received worker's compensation benefits from Venator. ${ }^{8}$ His injury required an absence from work for well over a year. ${ }^{9}$ Six months after being released to return to work, Gonzalez-Centeno aggravated his back injury and was forced to go home early from NCKRJDF. ${ }^{10}$ There ensued a series of meetings and phone calls, and the imposition of reporting requirements (apparently unique to Gonzalez-Centeno) that ultimately led to his firing and this suit. ${ }^{11}$

The Gonzalez-Centeno court surveyed the surprisingly few cases from other jurisdictions dealing with retaliation by one employer based on a worker's compensation claim filed against another employer and found that the majority of courts permitted the cause of action. ${ }^{12}$ The only court that refused to recognize such a cause of action was the Kentucky Supreme Court. ${ }^{13}$ That court reasoned that only the employer who fired the employee and against whom a worker's compensation

\footnotetext{
4. Brigham v. Dillon Cos., Inc., 262 Kan. 12, 18-20, 935 P.2d 1054, 1059-60 (1997).

5. 278 Kan. 427,101 P.3d 1170 (2004).

6. Id. at 1175 .

7. Id. at 1172 .

8. Id.

9. Id.

10. Id.

11. Id. at $1172-73$.

12. Id. at 1173-75; see also Darnell v. Impact Indus., Inc., 473 N.E.2d 935, 937 (IIl. 1984) (finding no difference between a normal retaliatory discharge claim and a claim brought against an employer who did not have the worker's compensation claim filed against it); Goins v. Ford Motor Co., 347 N.W.2d 184, 189 (Mich. Ct. App. 1983) (stating that there is "no reason . . to limit [retaliatory discharge] only to employers who fire employees who file claims against them rather than against previous employers"); Taylor v. Cache Creek Nursing Ctrs., 891 P.2d 607, 610 (Okla. Civ. App. 1994) (stating that to exempt subsequent employers from the retaliatory discharge statute would defeat the legislative purpose of the statute); Hayes v. Computer Scis. Corp., No. M200101611-COA-R3-CV, 2003 WL 113457, at *3 (Tenn. Ct. App. Jan. 14, 2003) (holding that the Oklahoma statute addressing retaliatory discharge applied to subsequent employers).

13. See Nelson Steel Corp. v. McDaniel, 898 S.W.2d 66, 68 (Ky. 1995) (holding that the seminal case in Kentucky does not allow a cause of action in the multiple-employer situation).
} 
claim was filed would have a retaliatory motive. "[T] another employer would be [merely] economic, that is, concern that its insurance rates might be affected by the employee's history." "14 The Kansas Supreme Court rejected this reasoning as "elevating the significance of motive and individual conduct over the public good." 15

The one point on which the majority view could be distinguished from Gonzalez-Centeno was that the majority-view cases all involved retaliation by a current employer because of a claim against a former employer, but the Supreme Court thought the reasoning applied equally well to the concurrent-employer situation presented in GonzalezCenteno. ${ }^{16}$

Gonzalez-Centeno involved two other important aspects of the worker's compensation retaliatory discharge cause of action. The first is the nagging problem created for employers by language in Coleman $v$. Safeway Stores, Inc., ${ }^{17}$ a 1988 decision in which an employee who missed work for surgery required by a compensable injury was fired for failing to call in daily to report her absences. The Supreme Court reversed the district court's grant of summary judgment to the employer, and in the syllabus it said:

Allowing an employer to discharge an employee for being absent or failing to call in an anticipated absence as the result of a work-related injury allows an employer to indirectly fire an employee for filing a workers' compensation claim, a practice contrary to the public policy of this state.

Subsequent Kansas cases tried to make it clear that Coleman did not automatically give a cause of action to an employee who was fired because he or she remained unable to perform the duties of the job because of a work-related injury. ${ }^{19}$ But the distinction between an actionable retaliatory discharge and a nonactionable firing for excessive

\footnotetext{
14. Gonzalez-Centeno, 101 P.3d at 1174 (citing Nelson Steel, 898 S.W.2d at 68-69).

15. Id. at 1174-75.

16. Id. at 1175 .

17. 242 Kan. 804, 752 P.2d 645 (1988), overruled by Gonzalez-Centeno, 101 P.3d 1170.

18. Id. at $645-46$.

19. See, e.g., Rowland v. Val-Agri, Inc., 13 Kan. App. 2d 149, 153, 766 P.2d 819, 822 (Kan. Ct. App. 1988) (distinguishing this case from Coleman based on the fact that "in Coleman[,] . . the plaintiff could return to her job"). Coleman was handed down in March 1988; Rowland came down in July of the same year. Kansas courts later reinforced "the view that an employee who cannot return to his former position does not have a retaliatory discharge claim." E.g., Griffin v. Dodge City Coop. Exch., 23 Kan. App. 2d 139, 146, 927 P.2d 958, 964 (Kan. Ct. App. 1996)
} 
absenteeism or for failure to report or call in remains difficult to determine. ${ }^{20}$

In Gonzalez-Centeno, defendant NCKRJDF argued that it fired the plaintiff for insubordination because he failed to speak to its Director or Assistant Director when he called in sick, as he had explicitly been told to do. On appeal, Gonzalez-Centeno relied on the broad language from Coleman, arguing that firing a worker for failing to talk to a specific person when calling in sick from a work-related injury states a claim for retaliatory discharge. The court rejected such a broad statement of Kansas law: "[W]hether an employer's discharging an employee for failing to call in an anticipated absence that results from a work-related injury gives rise to liability is a question of fact. Language to the contrary in Coleman . . . is disapproved." ${ }^{21}$ The court noted the factual differences between Coleman and Gonzalez-Centeno. In Coleman the employee was under the care of the company's doctor, who was reporting her condition to the employer, and she missed work because of surgery caused by a work-related injury. ${ }^{22}$ Thus, a requirement that she report absences on a daily basis was "entirely superfluous" 23 under the circumstances. In Gonzalez-Centeno, on the other hand, the employee's injury occurred while he was working for another employer, and he was not under the care of NCKRJDF's doctor. Moreover, at the time of the absences that led to his firing, he had recovered from his surgery and returned to work at NCKRJDF; then he began to accumulate additional absences caused by his back pain. According to the court, these absences were not predictable, and NCKRJDF relied on Gonzalez-Centeno to notify it of his absences so that it could obtain a replacement for him. Therefore, the call-in requirement was reasonable.

Finally, the court turned to the burden-shifting scheme used to analyze worker's compensation retaliation cases in Kansas. First adopted by the Kansas Supreme Court for worker's compensation retaliation cases in Rebarchek $v$. Farmers Cooperative Elevator \& Mercantile Ass' $n{ }^{24}$ this scheme is based on the McDonnell

20. The calculus has been further complicated by requirements of reasonable accommodation under the Americans with Disabilities Act, 42 U.S.C. $\S \S 12101-12213$ (2000), if the injured employee has a disability as defined by the Act, and by the Family and Medical Leave Act, 29 U.S.C. $\$ \S 2601-2654$ (2000), if the employee's injury satisfies the requirements of a "serious health condition," 29 U.S.C. $\$ 2611$ (11) (2000) and 29 § C.F.R. 825.114 (2007).

21. Gonzalez-Centeno, 101 P.3d at 1175.

22. Id. at $1175-76$.

23. Id. at 1176 .

24. 272 Kan. 546, 553, 35 P.3d 892, 898 (2001); see also, e.g., SanJuan v. IBP, Inc., 160 F.3d 1291, 1298 (10th Cir. 1998) (discussing the burden-shift in worker's compensation retaliation cases); 
Douglas/Burdine ${ }^{25}$ allocation-of-burdens analysis for employment discrimination cases. The court has also used this analysis in discrimination cases under the Kansas Act Against Discrimination ${ }^{26}$ and in employee free-speech cases. ${ }^{27}$ The elements of a plaintiff's prima facie case in a worker's compensation retaliatory discharge cause of action are: (1) the plaintiff filed a claim for worker's compensation benefits or sustained an injury for which he or she might assert a claim in the future; (2) the employer knew of the plaintiff's injury; (3) the employer fired the plaintiff; and (4) there was a causal connection between the plaintiff's protected activity and the firing. ${ }^{28}$ If a plaintiff makes this showing, the burden shifts to the employer to "articulate a legitimate, nonretaliatory reason for terminating the employee." 29 When the employer makes this showing, which presumably should not be difficult, the plaintiff bears the burden of proving, by a preponderance of the evidence, that the reasons offered by the employer were a pretext for wrongful termination. ${ }^{30}$

Although the McDonnell Douglas analysis has not always proved easy to apply in Title VII cases, where plaintiffs often have evidence in the form of racial, ethnic, or sexist remarks or epithets, as well as the circumstantial evidence for which the analysis was created in the first place, the Gonzalez-Centeno court had no trouble applying its scheme to the facts before it. It was clear to the court that Gonzalez-Centeno had made out his prima facie case. ${ }^{31}$ NCKRJDF articulated a legitimate, nonretaliatory reason for firing $\mathrm{him}^{32}$ - that he failed to report his absences to the appropriate employer officers. ${ }^{33}$ Therefore, to withstand NCKRJDF's motion for summary judgment, Gonzalez-Centeno had only to produce "any evidence from which a reasonable inference could be drawn that NCKRJDF's reason was a pretext." 34 He showed that the

Robinson v. Wilson Concrete Co., 913 F. Supp. 1476, 1483 (D. Kan. 1996) (same).

25. Tex. Dep't of Cmty. Affairs v. Burdine, 450 U.S. 248, 252 (1981); McDonnell Douglas Corp. v. Green, 411 U.S. 792, 802 (1973); see also, e.g., BARBARA LindEMANN \& PAUL Grossman, C. GEOFFREY WEIRICH, EDITOR-IN-CHIEF, I EMPLOYMENT DISCRIMINATION LAW 1191 (4th ed. 2007).

26. See, e.g., Woods v. Midwest Conveyor Co., 231 Kan. 763, 766, 648 P.2d 234, 238 (1982) (discussing the burden-shift in a Kansas Act Against Discrimination case).

27. See, e.g., Larson v. Ruskowitz, 252 Kan. 963, 973-75, 850 P.2d 253, 261-62 (1993)

(discussing an employee's right to free speech).

28. Gonzalez-Centeno, 101 P.3d at 1177.

29. Id.

30. Id. at 1178 .

31. Id.

32. Id.

33. Id. at 1176 .

34. Id. at 1178 . 
employer knew his absences resulted from a work-related injury, that he was the only employee NCKRJDF required to speak to the Director or Assistant Director when reporting his absences, and that he was fired after only one warning about his failure to do so. ${ }^{35}$ This, the court said, raised an inference favorable to Gonzalez-Centeno, and it reversed the district court's grant of summary judg.nent to the employer. ${ }^{36}$

Rebarchek v. Farmers Cooperative Elevator and Mercantile Ass ' $n{ }^{37}$ contains a few other points of interest. Rebarchek had recurring back problems, of which his employer was aware, throughout $1994 .^{38}$ In November 1994, he notified his employer that he had reinjured his back. $^{39}$ He alleged a pattern of retaliatory conduct by his supervisors, almost all of which took place in November. ${ }^{40}$ In March 1995, he had surgery. On April 17, 1995, he returned to work with light-duty restrictions, and on April 24, 1995, he was fired. ${ }^{41}$ The employer argued, and the district court held, that Rebarchek failed to prove the fourth element of his prima facie case of retaliatory discharge-causationbecause too much time had passed between his engaging in a protected activity and his firing. ${ }^{42}$ Employment discrimination law has produced an entire line of cases parsing the question of when temporal proximity between the protected act and the adverse action, standing alone, is enough to create a triable issue on causation. ${ }^{43}$ The court noted that Rebarchek's supervisor displayed anger and took punitive actions against Rebarchek at the time he filed his worker's compensation claim, but then all was quiet until Rebarchek returned to work after his surgery in midApril. ${ }^{44}$ The following sentence consists of the court's entire explanation of its reasoning for holding that Rebarchek had made out an inference of

\footnotetext{
35. Id.

36. Id. For another case applying the burden-shifting analysis under Kansas law to a retaliatory firing for excessive absences, see generally Bausman v. Interstate Brands Corp., 252 F.3d 1111 (10th Cir. 2001).

37. 272 Kan. 546, 35 P.3d 892 (2001).

38. Id. at 895 .

39. Id.

40. Id. at $895-96$.

41. Id. at 896 .

42. Id. at $899-900$.

43. Compare O'Bryan v. KTIV Television, 64 F.3d 1188, 1193 (8th Cir. 1995) (three months between filing complaints and firing still was enough to establish a general issue of material fact as to causation) and Ramirez v. Okla. Dep't of Mental Health, 41 F.3d 584, 596 (10th Cir. 1991) (one and one-half months between protected activity and adverse action may establish causation), with Gagnon v. Sprint Corp., 284 F.3d 839, 851-52 (8th Cir. 2002) (one month between response to EEOC claim and adverse action not enough for causation) and Richmond v. ONEOK, Inc., 120 F.3d 205, 209 (10th Cir. 1997) (three months not enough to establish causation).

44. Rebarchek, 35 P.3d at 900.
} 
causation: "The passage of slightly more than 5 uneventful months before Rebarchek was discharged probably approaches the limit that would be recognized as part of a pattern for the purpose of establishing a causal connection between the protected activity and termination."45 Unhelpful as the court was here, it appears at least to have established the outer limit on how far temporal proximity arguments can be pushed by a plaintiff. $^{46}$ And one might also conclude that Rebarchek proves once again to the cynics among us the truth of the old adage that revenge is a dish best served cold.

Bracken v. Dixon Industries, Inc. ${ }^{47}$ is, based on the facts presented by the Kansas Supreme Court, a straightforward application of the burdenshifting analysis to uphold a grant of summary judgment in favor of the employer. The employer had a drug testing policy that required alcohol and drug testing of employees in certain circumstances, including when an employee was involved in an on-the-job accident or when an employee was sent to the company doctor or to the hospital. ${ }^{48}$ Under the policy, any employee who tested positive was fired. ${ }^{49}$ Bracken asked for time off to see her physician for recurring pain in her hands and arms. ${ }^{50}$ Her supervisor recommended that she see one of the company's doctors. $^{51}$ She did, submitted to a drug test, and tested positive for marijuana. $^{52}$ Confirmatory testing also was positive, and Bracken was fired. ${ }^{53}$ She sued for retaliatory discharge, claiming the positive drug test was a pretext for the real reason she was fired, that she was about to file a worker's compensation claim. ${ }^{54}$ The Supreme Court agreed with the lower courts that she was unable to create an issue of fact, or indeed, "any evidence of substance" that the drug testing policy was being used as a pretext. ${ }^{55}$ Bracken knew of the employer's drug testing policy and had even been tested once before, in 1990, when she had seen the company's doctor $;{ }^{56}$ she admitted she had smoked marijuana the night

\footnotetext{
45. Id.

46. See White v. Tomasic, 31 Kan. App. 2d 597, 602-05, 69 P.3d 208, 212-13 (Kan. Ct. App. 2003) (three weeks between protected activity and firing sufficient to show causation).

47. 272 Kan. 1272,38 P.3d 679 (2002).

48. Id. at 681 .

49. Id.

50. Id.

51. Id.

52. Id.

53. Id.

54. $1 d$.

55. Id. at 684 .

56. Id. at 681 .
} 
before she was tested this time; ${ }^{57}$ there was evidence that at least one other employee had tested positive for drugs and been fired; and there was no evidence that any other employee who tested positive was not fired. ${ }^{58}$

The Kansas Court of Appeals decided two worker's compensation retaliation cases during the Survey period. In Gertsch v. Central Electropolishing Co. ${ }^{59}$ the plaintiff, Gertsch, was injured when he rushed into a building to look for victims of a toxic chemical reaction. ${ }^{60} \mathrm{He}$ was not wearing a safety mask and suffered lung damage when he inhaled the toxic fumes. While Gertsch was off work recovering from his injuries, the employer fired him for failing to call in every day. Gertsch was not released to return to work until sometime after the firing. The employer argued it could not be held liable for retaliatory discharge because under the rule of Rowland v. Val-Agri, Inc. ${ }^{61}$ and cases following it, a plaintiff who is unable to return to work may not maintain a wrongful discharge cause of action. The court of appeals rejected the argument under the facts of this case, holding that:

The requirement that an injured employee be able to return to his or her former position will not preclude an injured employee's claim for retaliatory discharge when the injured employee can show a retaliatory motive on the part of the employer before the employer had ample evidence that the injured employee would be unable to perform his or her former job. ${ }^{62}$

The second court of appeals decision, White v. Tomasic, ${ }^{63}$ involved a temporal proximity issue. White, an investigator for the Wyandotte County District Attorney, was injured on the job on March 7, 1995, and filed a worker's compensation claim at some point afterward. ${ }^{64}$ Events between March and September are not clear from the court's opinion, but White did not come to work or call in between September 28 and October $18 .^{65}$ On October 11, 1995, Tomasic sent White a letter notifying him that he was an "excessive user of sick leave"" and attached a copy of the county's sick leave and leave without pay

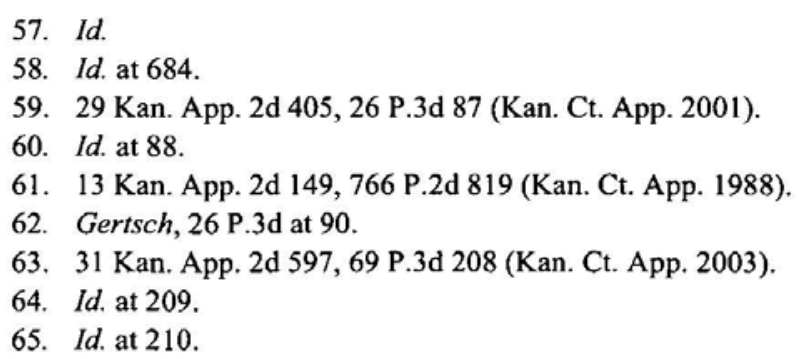


policies. $^{66}$ On October 18, Tomasic and White met, and during the meeting, Tomasic fired White. ${ }^{67}$ The district court granted judgment as a matter of law in the defendant's favor at the close of the plaintiff's case. On appeal the question was whether White had made out the fourth element of his prima facie case, the causal connection between White's protected activity and his firing. ${ }^{68}$ Tomasic argued that the relevant time period was the seven months between White's injury in March and the firing in October; without evidence of a pattern of retaliatory conduct on Tomasic's part during that period, White would not have made a prima facie showing of causation. ${ }^{69}$ After all, in Rebarchek, the Kansas Supreme Court had just set the outer limit for temporal proximity at five months. ${ }^{70}$ The court of appeals disagreed with Tomasic's measurements. To the court, the evidence clearly showed that White was fired for missing work, and therefore, the relevant period of time should be measured between the beginning of the absences and the firing. ${ }^{71}$ Looking at the evidence in a light most favorable to the plaintiff, the absences that led to White's firing began on September 28, and he was fired on October 18. This period of a little less than three weeks was sufficient to avoid judgment as a matter of law, and the case was reversed and remanded for a new trial. ${ }^{72}$

\section{B. Firings for Whistleblowing}

In Palmer v. Brown, ${ }^{73}$ the Kansas Supreme Court recognized a tort cause of action for retaliatory discharge for whistleblowing and set forth the elements of the claim. The plaintiff must prove by clear and convincing evidence that

a reasonably prudent person would have concluded the employee's coworker or employer was engaged in activities in violation of rules, regulations, or the law pertaining to public health, safety, and the general welfare; the employer had knowledge of the employee's

66. Id.

67. Id.

68. Id.

69. Id. at 212 .

70. Id. (citing Rebarchek v. Farmers Coop. Elevator \& Mercantile Ass'n, 28 Kan. App. 2d 104,

13 P.3d 17 (Kan. Ct. App. 2000), aff'd in part, rev'd in part 272 Kan. 546, 35 P.3d 892 (2001)).

71. Id.

72. Id. at 213.

73. 242 Kan. 893, 752 P.2d 685 (1988). 
reporting of such violation prior to the discharge of the employee; and the employee was discharged in retaliation for making the report.

Unlike other states, Kansas has not seen much litigation in which plaintiffs have made arguments about the connection between the reason for their firing and some broadly drawn "public policy."75 If these arguments appear anywhere in the reported Kansas cases, it is in the whistleblowing arena, as plaintiffs try to fit their complaints into Palmer's requirements.

An example of this phenomenon is found in Goodman v. Wesley Medical Center, L.L.C. ${ }^{76}$ The plaintiff was a nurse at Wesley Medical Center who had long complained about staffing and had sometimes refused to accept patient assignments. In May 2000, a plaintiff's attorney in a medical malpractice case that alleged negligence in understaffing contacted Goodman. Goodman had not been involved in the care of the patient involved in that case, but she met with the plaintiff's attorney, agreed to be a witness on behalf of the patient, and gave the attorney documents she said would prove the claim of understaffing. The documents included information about Wesley patients other than the one represented by the attorney. When Wesley learned about these documents, it fired Goodman for breaching Wesley's policies on patient confidentiality. Goodman sued, claiming she had been reporting violations pursuant to the Kansas Nurse Practice Act (KNPA), which provides that a nursing license can be revoked or suspended if the nurse is found to have committed an act of "professional incompetency," as defined in the Act. ${ }^{77}$ The court held that because the KNPA's provisions are "vague, factually-dependent standard-of-care requirements" and not definite or specific rules, they could not be the basis of a whistleblowing cause of action. ${ }^{78}$

74. Id. at 690 .

75. See, e.g., Gardner v. Loomis Armored, Inc., 913 P.2d 377, 384 (Wash. 1996) (finding that a state policy "of saving persons from life threatening situations" was violated when an armored truck guard was fired for leaving a truck unattended to aid a bank manager who was being chased by a man with a knife).

76. 276 Kan. 586, 78 P.3d 817 (2003).

77. KAN. STAT. ANN. $§ 65-1120(a)(3)$ (2006); see also id. $\S 65-1120(\mathrm{e})$ (defining professional incompetency).

78. Goodman, 78 P.3d at 822. Goodman contains another issue, the alternative-remedies doctrine, which will be discussed below. 


\section{Firings in Violation of Other Public Policies}

On a question certified from the Tenth Circuit, the Kansas Supreme Court held in Hysten v. Burlington Northern Santa Fe Railway Co ${ }^{79}$ that Kansas recognizes an action in tort based on the firing of an employee in retaliation for his or her exercise of rights under the Federal Employers Liability Act. The court rejected the employer's attempt to limit the Kansas at-will exceptions to two, those contained in Murphy and Palmer, as well as its argument that only a public policy based on state law would support a claim. To the employer's "floodgates" argument, the court replied, "[n]ot every public policy underlying a federal statute or regulation is identical to a Kansas public policy as previously clearly expressed in our statutes, regulations, or case law."80 Therefore, Kansas courts will recognize a retaliatory suit based on a federal statute that is grounded in exactly the same public policy as the Kansas worker's compensation law on which the Murphy cause of action rests. How far the court will be willing to go in extending the statutory bases on which plaintiffs may rest their public policy retaliatory discharge claims remains to be seen.

\section{Alternative-Remedies Doctrine}

Inherent in the public policy/wrongful discharge cause of action is the conflict between a statute that contains its own remedial scheme and the common law tort claim in which an employee argues that his or her firing violated the public policy embodied by that statute. May a plaintiff avoid the statutory remedies and sue in tort instead? In Flenker $v$. Willamette Industries, Inc., ${ }^{81}$ the Kansas Supreme Court applied the alternative-remedies doctrine to answer that question. ${ }^{82}$ In Flenker the court concluded that the Palmer cause of action for whistleblowing was not precluded by the whistleblower regulations of the federal Occupational Safety and Health Act (OSHA). ${ }^{83}$ The OSHA remedy was inadequate, according to the court, because (1) the period for filing claims under OSHA was only thirty days; (2) the Secretary of Labor had

79. 277 Kan. 551,108 P.3d 437 (2004).

80. Id. at 441.

81. 266 Kan. 198,967 P.2d 295 (1998).

82. Id. at 300 .

83. 29 U.S.C. $\S \S 651-678(2000)$. 
sole discretion whether to pursue the employee's claim; and (3) the statute contained no guidelines for making that decision: ${ }^{84}$

In Hysten, on a certified question from the Tenth Circuit, the Kansas Supreme Court held that the remedies available to an employee under the Railway Labor Act (RLA) do not preclude a tort action for discharge in retaliation for that employee's exercise of rights under the Federal Employers Liability Act. ${ }^{85}$ The remedy under the RLA is arbitration, and the court noted that it has been critical of forcing employees into arbitration when their claims sound in the public policy tort area. ${ }^{86}$ Arbitration, the court remarked in Hysten, is a process "far less than ideal." ${ }^{, 87}$ Although Hysten would have a right to appeal any adverse ruling of the arbitration board to federal district court, the court found "the narrowness of the standard of review on that appeal robbed him of most of his control over the issues to be addressed." 88 Moreover, compensatory damages for pain and suffering and punitive damages are not available under the RLA. $^{89}$ In a retaliatory discharge action, deterrence of similar employer conduct in the future by permitting the recovery of more than pure economic loss is "essential," said the court. ${ }^{90}$ For these reasons, the RLA remedy was not adequate, and Hysten could pursue his retaliatory discharge claim as a tort.

On the other hand, the court supported its ruling in Goodman v. Wesley Medical Center, L.L.C., ${ }^{91}$ also discussed above, by emphasizing that the reporting provisions of the Kansas Risk Management Act $(\mathrm{KRMA})^{92}$ provide an adequate alternative remedy to plaintiff's wrongful discharge claim. $^{93}$ The KRMA requires health care professionals to report incidents that are "or may be below the applicable standard of care and [have] a reasonable probability of causing injury to a patient; or ... [that] may be grounds for disciplinary action by the

\footnotetext{
84. Flenker, 967 P.2d at 301.

85. Hysten, 108 P.3d at 438.

86. Id. at 444 (citing Coleman v. Safeway Stores, Inc., 242 Kan. 804, 813-14, 752 P.2d 645, 651-52 (1988), overruled on other grounds by Gonzalez-Centeno v. N. Cent. Kan. Reg'l Juv. Det. Facility, 278 Kan. 427, 101 P.3d 1170 (2004) (overruling previous decisions on this issue and permitting employees covered by a collective bargaining agreement to maintain a tort suit for discharge in retaliation for filing a worker's compensation claim)).

87. Id.

88. Id.

89. Id. at 445 .

90. Id.

91. 276 Kan. 586,78 P.3d 817 (2003).

92. KAN. STAT. ANN. $\S \S 65-4921$ to -4930 (2006).

93. Goodman, 78 P.3d at 824 .
} 
appropriate licensing agency,"94 and it protects health care providers from discharge or discrimination for engaging in mandatory reporting. ${ }^{95}$ The statutory remedy permits a civil suit brought by the aggrieved employee, recovery of wages or other lost benefits, plus a civil penalty in an amount not to exceed the amount of the lost wages and benefits, and reasonable attorney's fees and costs. ${ }^{96}$ This remedy suffers from none of the defects the court found in Flenker. ${ }^{97}$ The employee has full decisionmaking authority over whether to bring suit in state court, and the common law remedy is expanded with the statutory punitive damages and attorney's fees. ${ }^{98}$ Therefore, the court held that the KNPA does not provide a public policy basis to support retaliatory discharge claims in the health care industry. ${ }^{99}$

In 2001, the Kansas Supreme Court decided two complicated cases involving state employees who claimed, among other things, that they were fired in retaliation for their whistleblowing activities. In Prager $v$. Kansas Department of Revenue $e^{100}$ and Connelly v. Kansas Highway Patrol $^{101}$ the court held that the Kansas Whistleblower Act ${ }^{102}$ provides a state classified civil service employee with an adequate alternative statutory remedy for whistleblowing. ${ }^{103}$

\section{INTENTIONAL INFLICTION OF EMOTIONAL DISTRESS}

On a certified question from the United States District Court for the District of Kansas, the Kansas Supreme Court held in Hallam v. Mercy Health Center of Manhattan, Inc. ${ }^{104}$ that the statute of limitations for a claim of intentional infliction of emotional distress and outrage is two years, pursuant to section $60-513(\mathrm{a})(4)$ of the Kansas Statutes. ${ }^{105}$

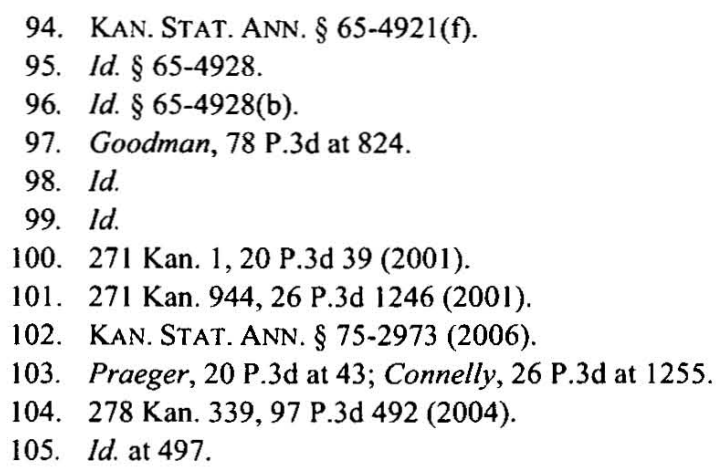




\section{NEGLIGENT HIRING}

Suits alleging negligent hiring, supervision, or retention have not received much favor in the Kansas courts, and the example arising during the survey period was no exception. In Prugue v. Monley ${ }^{106}$ the plaintiff's son was injured in an automobile accident that was caused by an employee of a bar who admitted to having consumed four or five mixed drinks in a two-hour period while at work the night of the accident. ${ }^{107}$ The court noted that in every Kansas case in which an employer has been found liable on a theory of negligent hiring, the employee's actions against the plaintiff took place on the employer's premises at "the time employment services were normally rendered."108 Moreover, the only evidence suggesting the bar employee might not have been fit for his job was a DUI citation he received almost five years before the accident. ${ }^{109}$ He was never convicted because he was allowed to enter into a diversion agreement, and he remained eligible to work in a drinking establishment in the state of Kansas. ${ }^{110}$

\section{IMPLIED CONTRACTS}

\section{A. Implied Contract Found}

Kansas continues to recognize implied employment agreements as an exception to the employment-at-will doctrine. Whether an implied agreement will be found to restrict an employer's ability to terminate an employee at will depends on the totality of the factual circumstances. ${ }^{111}$ A mutual intent to contract must be present, and an employee must provide evidence of more than a unilateral expectation of continued employment. $^{112}$ While federal court decisions rejecting implied contract claims outnumbered those recognizing them, sufficient evidence to imply an agreement was found in the following cases. Implied agreements were found despite disclaimers in employee handbooks.

\footnotetext{
106. 29 Kan. App. 2d 635, 28 P.3d 1046 (Kan. Ct. App. 2001).

107. Id. at 1047-48.

108. Id. at 1050 (citing Schmidt v. HTG, Inc., 265 Kan. 372, 961 P. 2d 677 (1998)).

109. Id.

110. Id.

111. Inscho v. Exide Corp., 29 Kan. App. 2d 892, 896, 33 P.3d 249, 252 (Kan. Ct. App. 2001).

112. Id.
} 
In Stover v. Superior Industries International, Inc. ${ }^{113}$ the Kansas Court of Appeals upheld a jury verdict of breach of an implied employment contract. ${ }^{14}$ In ruling for the plaintiffs, the court reaffirmed that Kansas "recognizes an implied obligation on the employer to not terminate an employee arbitrarily where a policy or program of the employer, either express or implied, restricts the employer's right of termination at will." 15 The plaintiffs presented the following evidence: (1) an employee handbook that set forth progressive discipline steps, set up a ninety-day probationary period during which an employee could be terminated for any reason, and stated that the defendant would treat its employees fairly and respectfully and expected that employees would enjoy a long and challenging career with it; (2) a supervisor's manual that articulated the defendant's policy for resolving problems and avoiding the need to terminate employees; and (3) testimony from three members of the defendant's management team that defendant's policy was to terminate employees only for cause. ${ }^{116}$ The court found that, despite a disclaimer in the handbook, the plaintiffs provided sufficient evidence for the jury to infer an implied contract. ${ }^{117}$ In reaching this decision, the court relied on the absence of specific evidence that the disclaimer had been brought to the plaintiffs' attention (although the plaintiffs testified they received the handbook and were familiar with the policies articulated in it) and the supervisors' testimony that the defendant's policy was to terminate only for good cause. ${ }^{118}$

In Parker v. Life Care Centers of America, Inc., ${ }^{119}$ the United States District Court for the District of Kansas found that the plaintiff's testimony that she was told employees could not be terminated without going through the progressive discipline steps set out in the handbook was sufficient evidence to create an implied contract. ${ }^{120}$ This was so despite the existence of a statement in the employee handbook that employment could be terminated at any time. ${ }^{121}$

The District of Kansas again found sufficient evidence for a jury to imply an employment contract in Bell v. Board of County

113. 29 Kan. App. 2d 235, 29 P.3d 967 (Kan. Ct. App. 2000).

114. Id. at 973.

115. Id. at 970 (citing Brown v. United Methodist Homes for the Aged, 29 Kan. 124, 134, 815

P.2d 72, 81 (1991)).

116. Id. at 971 .

117. Id. at 972 .

118. Id. at $971-72$.

119. No. 04-1206-MLB, 2006 U.S. Dist. LEXIS 16865 (D. Kan. Mar. 31, 2006).

120. Id. at *30-*31.

121. Id. 
Commissioners. ${ }^{122}$ Plaintiff Bell brought his action against Jefferson County under 42 U.S.C. $\S 1983$, claiming a property interest in his employment despite the presumption that, in Kansas, public employment is at will. ${ }^{123}$ Bell, an emergency medical services (EMS) technician, claimed his evidence established an implied contract for employment for a definite term and, further, that he had a property interest in the grievance procedure set forth in the county's handbook. ${ }^{124}$ The county handbook stated several times that it was not intended to imply a contract of employment and that county employees were employed at will. ${ }^{125}$ The handbook also set out a grievance procedure, stating that "'involuntary dismissal is reserved for those cases that cannot be resolved by corrective counseling or in those cases where a major violation has occurred which cannot be tolerated." "'26 Bell presented evidence that the EMS director told him he could have a job as long as he satisfactorily performed his duties. ${ }^{127}$ Bell also presented the EMS director's testimony that employees could be fired only for cause. ${ }^{128}$ The court found Bell presented a genuine issue of material fact as to the existence of an implied contract or property interest. ${ }^{129}$

The same court found that a reasonable jury could find an implied agreement to provide certain sick pay based on the terms of the employee handbook. In Lines $v$. City of Ottawa ${ }^{130}$ the plaintiff alleged a breach of conditions of employment, asserting that he had an implied contract with Ottawa based on the city's sick leave policy (which stated that employees received sick leave credit at a rate of eight hours per month). ${ }^{131}$ The city handbook set out the policy, and although there was a disclaimer in the handbook, the disclaimer was not determinative because there was no evidence the plaintiff read it. ${ }^{132}$ In the end, the court found sufficient evidence of a mutual intent to contract based on the existence and terms of the sick leave policy itself. ${ }^{133}$ The court did not rely on any other evidence to support its ruling. ${ }^{134}$

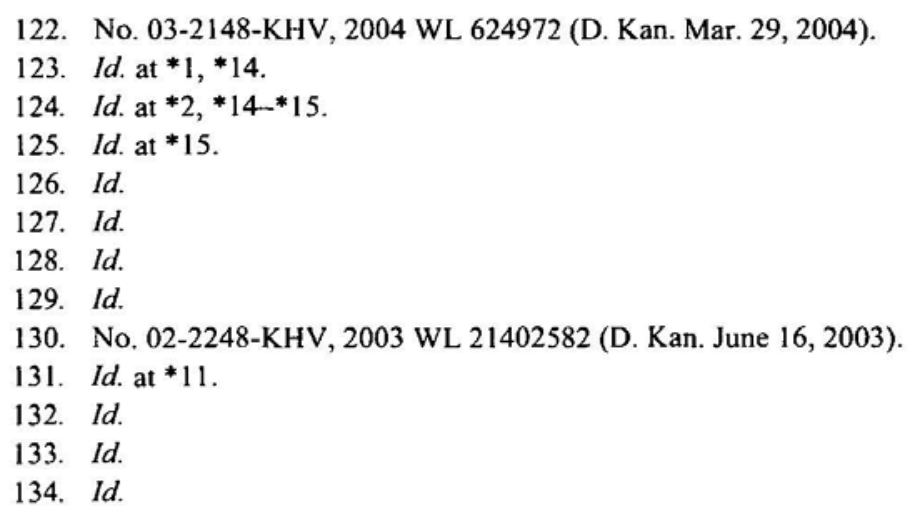




\section{B. No Contract Implied}

Other recent cases have found plaintiffs' evidence insufficient to establish implied contracts of employment. Disclaimers and other language in employee handbooks and manuals indicating that employment is at will continue to weigh heavy in the courts' analyses.

In Inscho v. Exide Corp., the Kansas Court of Appeals rejected a former employee's implied contract claim when an employee handbook disclaimed an employment contract, and the employee's other evidence consisted only of her own subjective beliefs, beliefs of other employees as expressed in a job survey, and the company's past practice of terminating employees only when they violated a company policy. ${ }^{135}$ The appellate court also rejected dicta in a prior appellate case suggesting that the existence of an implied contract is always a jury question. ${ }^{136}$ The court clarified that an employer can prevail on summary judgment if the employee presents evidence only of unilateral expectations of continued employment. ${ }^{137}$

While not dispositive, a disclaimer will undercut a plaintiff's implied contract claim if the plaintiff in fact read the disclaimer. ${ }^{138}$ Numerous cases continue to indicate that handbook language alone will generally be insufficient to show that the parties intended to enter into an agreement restricting the employer's ability to terminate its employees at will. In Zwygart v. Board of County Commissioners, ${ }^{139}$ the court found no implied contract existed when the terminated employee pointed only to statements in an employee manual regarding leave without pay. ${ }^{140}$ The court observed that when the "Tenth Circuit has stated that summary judgment [of an implied contract claim] is inappropriate, it has highlighted at least one other key factor" besides language in the handbook. ${ }^{141}$ Other cases reached similar results. ${ }^{142}$

135. 33 P.3d at $251-52$.

136. Id. at 252-53 (rejecting language in Stover v. Superior Indus. Int'l Inc., 29 Kan. App. 2d 235, 29 P.3d 967 (Kan. Ct. App. 2000)).

137. Id.

138. Henderson v. Montgomery County, 213 F. Supp. 2d 1262, 1278 (D. Kan. 2002). In Henderson, the court found the fact that the plaintiff read the handbook and the disclaimer language to "severely undercut the merits of plaintiff's [implied contract] claim." Id.

139. 412 F. Supp. 2d 1193 (D. Kan. 2006).

140. Id. at $1199-1200$.

141. Id. at 1200 .

142. See Wilson v. Training Plus, Inc., No. 03-2431-JWL, 2003 WL 22757929, at *4 (D. Kan. Nov. 13, 2003) (" $[\mathrm{A}] \mathrm{n}$ employment manual does not by itself provide sufficient evidence of an intent to form a contract under Kansas law; additional evidence bearing on the issue of the defendant's intent is required."); Conrad v. Bd. of Johnson County Comm'rs, 237 F. Supp. 2d 1204, 1256 (D. 
Similarly, while a disclaimer in a handbook does not automatically preclude the formation of an implied contract, in the absence of other evidence inconsistent with the disclaimer, the court will not find an implied agreement. ${ }^{143}$ In Wells v. Accredo Health Group, Inc., the plaintiff signed three documents in which he acknowledged his employment was at will. ${ }^{144} \mathrm{He}$ did not claim that he never saw the disclaimer, nor did he offer evidence inconsistent with the disclaimer. ${ }^{145}$ Thus, there was no implied contractual agreement to follow the handbook's progressive discipline policy. ${ }^{146}$

No implied contract could be inferred based on evidence that an employee's supervisor assured her that there would be a position for her after the supervisor's retirement. ${ }^{147}$ In Creason v. Seaboard Corp., there was no evidence that management ratified the supervisor's alleged guarantee or any other evidence of expressed intent on the part of the employer to change the plaintiff's at-will status. ${ }^{148}$ Similarly, evidence that an employer implemented progressive discipline procedures and had a practice of terminating employees only for what it deemed to be just cause was not sufficient to establish an implied contract when the employee signed a clear statement from the company that his employment was at will. ${ }^{149}$

A company policy that required employees to reimburse the company for the cost of intensive training if the employee quit within one year after the training was not evidence that a company intended to restrict its ability to terminate an employee without cause. ${ }^{150}$

In Conrad $v$. Board of Johnson County Commissioners, ${ }^{151}$ the court stated that to prevail on an implied contract claim, the plaintiff had to

Kan. 2002) (" $[\mathrm{A}]$ written personnel policy, which is not bargained for, is not alone sufficient to establish an implied contract."); Getz v. Bd. of County Comm'rs, 194 F. Supp. 2d 1154, 1168 (D. Kan. 2002) ("'A] written personnel policy, standing alone, is not sufficient to establish an implied contract of employment . . . as [it is] merely a unilateral expression of 'company policy."”).

143. See Wells v. Accredo Health Group, Inc., No. 05-2242-CM, 2006 WL 1913140, at *4 (D. Kan. July 11,2006 ) (finding that the plaintiff failed to establish an implied contract of employment when the employee handbook contained a disclaimer); McCauley v. Raytheon Travel Air Co., $152 \mathrm{~F}$. Supp. 2d 1267, 1273 (D. Kan. 2001) (finding that a manual giving nine possible reasons for termination and also stating that employment was at will did not support finding of implied contract).

144. Wells, 2006 WL 1913140 , at *4.

145. Id.

146. Id. at *5.

147. Creason v. Seaboard Corp., 263 F. Supp. 2d 1297, 1313-14 (D. Kan. 2003).

148. Id. at 1314 .

149. Ratcliff v. Coca-Cola Bottling Co., No. 00-1007-WEB, 2001 WL 310962 , at *8-*9 (D. Kan. Feb. 28, 2001).

150. McCauley v. Raytheon Travel Air Co., 152 F. Supp. 2d 1267, 1272-73 (D. Kan. 2001).

151. 237 F. Supp. 2d 1204 (D. Kan. 2002). 
show that her supervisors or others in management made statements to employees which were inconsistent with the disclaimer in the handbook or show some other evidence of mutual intent to contract. ${ }^{152}$ The plaintiff presented testimony from several supervisors stating they had not terminated employees without reason and that employees would not have been terminated without reason. ${ }^{153}$ She had evidence that one supervisor believed an employee had to go through the discipline policy before being terminated and that the county had to have a good reason to terminate. ${ }^{154}$ The supervisor also testified that in her "estimation," the county's at-will policy was in conflict with its "day-to-day" policy that good cause was needed to terminate an employee. ${ }^{155}$ The court found this evidence gave an indication of the employer's general practice, but it did not reflect what the employer represented to employees or to the plaintiff specifically. Thus, it did not otherwise indicate the employer's intent to create a contractual obligation. ${ }^{156}$

\section{County and Municipal Employees}

In a series of cases, courts have made it difficult for municipal employees to bring either an express or implied contractual claim of employment. Several federal courts recently relied on two Kansas Court of Appeals cases, Riddle v. City of Ottawa ${ }^{157}$ and Wiggins v. Housing Authority of Kansas City, ${ }^{158}$ in refusing to find an employment contract for various municipal employees. One federal court also has applied Riddle and Wiggins to bar a county employee's implied contract claim. ${ }^{159}$

In Riddle, a suspended employee of the Ottawa public safety department claimed he had a property interest in his employment that could not be taken without due process. In rejecting his claim, the court stated that in Kansas "an incumbent to a public office enjoys no property or vested interest in public office." 160 With regard to public employees, "the tenure of any office not provided for in the constitution may be

152. Id. at 1258 .

153. Id. at 1259 .

154. Id.

155. Id.

156. Id.

157. 12 Kan. App. 2d 714, 754 P.2d 465 (Kan. Ct. App. 1988).

158. 22 Kan. App. 2d 367, 916 P.2d 718 (Kan. Ct. App. 1996).

159. Dozier v. City of Overland Park, No. 06-2169-JWL, 2006 WL 2177859, at *5 (D. Kan. July 31, 2006)

160. Riddle, 754 P.2d at 468 (quoting Stoldt v. City of Toronto, 678 P.2d 153 (Kan. 1984)) (emphasis omitted). 
declared by statute, and when not so declared such office shall be held at the pleasure of the appointing authority." 161 The court found that no statute provided for a term of office for Ottawa city employees, or placed any limit on the city manager's power to suspend or remove an employee from office. ${ }^{162}$ Thus, the court held that Riddle did not "have a constitutionally protected property right" to his job as an Ottawa public safety officer. ${ }^{163}$ The court further refused to find that the Ottawa Personnel Regulations provided a legitimate claim of entitlement to continued employment, stating that the "rules and regulations are not state law, however, and cannot override" clear statutory or city code provisions. ${ }^{164}$

In Wiggins, terminated employees of the Housing Authority of Kansas City sued on an implied contract theory. ${ }^{165}$ The court rejected their claim, holding that any alleged contract with the plaintiffs was ultra vires and void and unenforceable. ${ }^{166}$ The court reasoned that the Housing Authority, as an agent of the city, had only such powers and authority as were granted to it by its enabling legislation, and its power to contract was limited to those powers specifically granted or necessarily implied. ${ }^{167}$ No legislation empowered the Housing Authority to enter into employment contracts for a definite term. ${ }^{168}$ Also, no such power was implied because it was not necessary to effectuate any other powers expressly granted. ${ }^{169}$ "In this case, there is no indication whatsoever that the Housing Authority cannot function and carry out its duties under the employment-at-will doctrine."170 Thus, the court held that the Housing Authority had no power to agree to employment for a specific term, and no such agreement existed or could otherwise be enforced. ${ }^{171}$

Relying on Riddle and Wiggins, and federal court cases applying them, the federal court in Dozier v. City of Overland Park ${ }^{172}$ found that, under a city manager form of government, all employees are terminable at will by statute, which precludes any basis for implied contractual

161. Id.

162. Id. at 469 .

163. Id.

164. Id

165. Wiggins v. Hous. Auth. of Kan. City, 22 Kan. App. 2d 367, 916 P.2d 718, 719 (Kan. Ct. App. 1996).

166. Id. at 722 .

167. Id. at 720 .

168. Id. at 722 .

169. Id.

170. Id.

171. Id.

172. No. 06-2169-JWL, 2006 WL 2177859 (D. Kan. July 31, 2006). 
rights or for a protected property interest in employment. ${ }^{173}$ In Dozier, the city of Overland Park employed the plaintiff as a code enforcement specialist for several years until his termination for alleged misconduct with a citizen during an inspection. ${ }^{174}$ The plaintiff argued he had an implied employment contract entitling him to certain post-termination proceedings, which the City failed to appropriately provide. ${ }^{175}$ The court found that "regardless of plaintiff"s factual allegations, he was barred by statute from entering into an implied contract" with Overland Park. . $^{176}$ " "Kansas law gives a city manager the power to remove employees without cause, and that power cannot be abridged by contract, implied or written, because the city manager lacks the authority to enter into a contract of employment for a specific term." "177

In another unpublished decision, ${ }^{178}$ the District of Kansas again applied Riddle and its progeny and denied a law enforcement officer formerly employed by the City of Wichita an implied contract claim. ${ }^{179}$ On at least one other occasion, a federal district court has expressed doubt about a city employee's ability to establish an implied contract claim. ${ }^{180}$ However, on a separate occasion, the court declined to apply Riddle to a city employee's claim that the city's sick leave policy created an implied contract. The court refused to grant summary judgment on the claim because the plaintiff claimed an implied contract based on the city's sick leave policy, not based on the city manager's representations, and because the plaintiff's claim did not relate to termination. ${ }^{181}$

Most recently, Riddle and its progeny were applied to bar a county hospital employee from claiming an implied contract. ${ }^{182}$ In Alderfer $v$.

173. Id. at $* 4-5$.

174. Id. at $* 1$.

175. See id. at *3 ("'[P]laintiff alleges a due process violation based on the City's failure to abide by the regulations in its own handbook when it terminated [him.]").

176. Id. at *5.

177. Id. (quoting Cragg v. City of Osawatomie, No. 95-2492-JWL, 1996 WL 707108, at *6 (D. Kan. Nov. 8, 1996), rev'd on other grounds, 143 F.3d 1343 (10th Cir. 1998)).

178. Najim v. City of Wichita, No. Civ.A. 04-1399-WEB, 2005 WL 2043426 (D. Kan. Aug. 24, 2005).

179. Id. at *3 (quoting Cragg, 1996 WL 707108, at*6); see also Warren v. City of Junction City, 176 F. Supp. 2d 1118, 1125 (D. Kan. 2001) (city manager had no power under Kansas law to enter into an implied contract of employment for continued employment with a city employee).

180. See Crowley v. City of Burlingame, 352 F. Supp. 2d 1176, 1182-83 (D. Kan. 2005) (expressing doubt whether police chief can establish implied contract of employment with city police offer), aff'd, 165 Fed. App'x 579 (10th Cir. 2006).

181. Lines v. City of Ottawa, No. Civ.A. 02-2248-KHV, 2003 WL 21402582, at *12 (D. Kan. June 16, 2003).

182. Alderfer v. Bd. of Trs. of Edwards County Hosp., No. 05-1084-MLB, 2006 WL 2548786, at *3-*6 (D. Kan. Aug. 31, 2006). 
Board of Trustees of Edwards County Hospital, the plaintiff entered into a written employment agreement with the county hospital, was employed for about two years, and then terminated. ${ }^{183}$ She filed a lawsuit alleging breach of contract and a violation of due process. The Board argued the alleged contract was void because it had no authority to enter into an employment contract for a fixed term. ${ }^{184}$ The district court relied on Kansas law that "'a public employee serves at the will of his or her employer unless that employer is specifically empowered to contract for employment on other terms." ${ }^{185}$ It held that no Kansas statute empowered the Board to enter into an employment contract for a specific term and that this power could not be implied in powers granted by the Kansas Hospital and Related Facilities Act. ${ }^{186}$ Therefore, the alleged written or express contract was void and no contract could otherwise be implied. ${ }^{187}$

\section{EXPRESS EMPLOYMENT CONTRACTS}

\section{A. Formation and Just Cause}

In Crump v. WLBB Broadcasting, L.L.C., ${ }^{188}$ an unpublished decision, the Kansas Court of Appeals examined whether a letter to the plaintiff setting out a specific salary for a twelve-month period of time established a one-year employment contract. The letter from WLBB Broadcasting, L.L.C. (WLBB) to the plaintiff, Crump, stated in pertinent part: "Your compensation will be a guaranteed salary of $\$ 60,000$ for a period of 12 months." 189 The court found that the letter was ambiguous, but it ultimately upheld the district court's ruling that the parties had contracted for employment for one year absent termination for cause. ${ }^{190}$

To determine the intent of the parties in an ambiguous agreement, the court applied the factors set forth in the Restatement (Second) of Agency section 442(b):

183. Id. at $* 1$.

184. Id. at *3.

185. Id. at *3 (quoting Wiggins v. Hous. Auth. of Kan. City, 22 Kan. App. 2d 367, 372, 916 P.2d 718, 722 (Kan. Ct. App. 1996)).

186. See id. at *5 (stating that the Kansas Hospital and Related Facilities Act "grants a board the power to hire, but not to hire for a fixed term" (citing KAN. STAT. ANN. § 19-4610(a) (2006))).

187. See id. at *6 (granting the defendant's motion for summary judgment).

188. No. 89,892, 2004 WL 90061, at *I-*2 (Kan. Ct. App. Jan. 16, 2004).

189. Id. at $* 2$.

190. Id. at *4. 
Factors that tend to show the agreement was for a certain time unit include: (1) one party pays consideration aside from his promise to employ or to serve; (2) the employment is of a type that would not likely be temporary; (3) the employer has notice that the employee has made an important change in his life in order to accept the position; and (4) the employee has given up a position of some value in order to enter the employment. ${ }^{19}$

The court also considered comment $\mathrm{b}$ to $\S 442$ which provides:

"The fact that a servant or other agent is employed under a contract which merely specifies a salary proportionate to units of time which are commonly used for the purposes of accounting or payment, such as a month or a year, does not, of itself, indicate that the parties have agreed that the employment is to continue for the stated unit of time. Such a specification merely indicates the rate at which the salary is earned or is to be paid, and either party is privileged to terminate the relationship at any time unless further facts exist." 192

After finding the letter ambiguous, the court looked to extrinsic evidence and found evidence of several factors supporting the conclusion that the parties intended a one-year term of employment. ${ }^{193}$ Crump testified that WLBB offered him " $\$ 60,000$ a year for the first year for a 12-month period" and that he told WLBB he wanted guaranteed employment for a specified period. ${ }^{194}$ Crump also presented evidence that he left a valuable position to take the WLBB job. ${ }^{195}$ The court found substantial evidence to support the trial judge's decision that the parties intended a one-year term of employment. ${ }^{196}$

The Crump court also explained what termination for cause requires. Citing the Tenth Circuit Court of Appeals, it stated as follows:

[Cause for discharge] is a shortcoming in performance which is detrimental to the discipline or efficiency of the employer. Incompetency or inefficiency or some other cause within the control of the employee which prohibits him from properly completing his task is

191. Id. at *3 (citing RESTATEMENT (SECOND) OF AGENCY $\S 442$ (b) (1958)).

192. Id. (citing RESTATEMENT (SECOND) OF AGENCY $\S 442 \mathrm{cmt}$. b (1958)).

193. Id. at *4.

194. Id. at*1. WLBB's evidence and some of Crump's deposition testimony conflicted with this trial testimony. Id.

195. Id. at *4.

196. Id. 
also included within the definition. A discharge for cause is one which is not arbitrary or capricious, nor is it unjustified or discriminatory.

The court also upheld the district court's determination that seventeen absences in six months did not meet this standard. ${ }^{198}$ Management allowed Crump to take off these days without reprimanding him or telling him it was not allowed, and management never gave Crump a warning or a performance evaluation before terminating him. ${ }^{199}$

\section{B. Duress and Covenant of Good Faith}

A threat to fire an employee if he did not sign a personal services agreement did not constitute duress in Litton v. Maverick Paper Co. ${ }^{200}$ In Litton, the employee "asked to change his employment status to independent contractor," then later signed a personal services agreement to effectuate the change. ${ }^{201}$ Furthermore because the personal services agreement could be "“terminated by either party upon 90 days written notice to the other party," the court found that the agreement did not contain an implied covenant of good faith. ${ }^{202}$ Under Kansas law, the court explained, "an employment contract that can be terminated without cause does not imply a duty of good faith and fair dealing."203

\section{Interpretation of Specific Terms}

After analyzing the parties' proposed sources of definitions, case definitions, and all provisions within the employment agreement for consistency, the Kansas Court of Appeals held in Brodsky v. St. Francis Hospital \& Medical Center, Inc. that the term "retirement" is not ambiguous. $^{204}$ It found the term "retire" in the applicable employment agreement meant "something more than mere separation or termination"

197. Id. at *5 (quoting Weir v. Anaconda Co., 773 F.2d 1073, 1080 (10th Cir. 1985) (applying Kansas law)).

198. Id.

199. Id.

200. 388 F. Supp. 2d 1261, 1291 (D. Kan. 2005).

201. Id.

202. Id. at 1292 .

203. Id. (citing St. Catherine Hosp. of Garden City v. Rodriguez, 25 Kan. App. 2d 763, 765, 971 P.2d 754, 756 (Kan. Ct. App. 1998)).

204. No. 90,555, 2004 WL 1715000 , at *5-6 (Kan. Ct. App. July 20, 2004). 
of employment and did not, as the plaintiff (former employee) argued, include moving one's practice to, or resuming it in, another state. ${ }^{205}$

\section{NONCOMPETITION COVENANTS}

\section{A. Validity and Scope}

In the last several years, key decisions regarding noncompetition covenants have involved employees in the health care industry. Courts have examined whether a surgical group can have a legitimate interest in its referral sources, whether a noncompetition agreement that protects an alleged illegal kickback arrangement is valid, whether an employer may enforce a noncompetition covenant that covers geographic areas in which the employer did not compete, and whether a covenant threatened the public welfare because it created a shortage of physicians.

In Kansas, a surgical group can have a legitimate business interest in its referral sources and it may protect this interest in a reasonable covenant not to compete. In Idbeis v. Wichita Surgical Specialists, $P . A .{ }^{206}$ the Kansas Supreme Court examined whether a surgical group, Wichita Surgical Specialists, P.A. (WSS), could enforce a noncompetition covenant that attempted to protect its referral sources. ${ }^{207}$ The court held that a surgical group could have a legitimate business interest in its referral sources, and that WSS in fact had such a legitimate business interest. ${ }^{208}$ Cases cited by the parties indicated that other jurisdictions are "split on the issue of whether referral sources are a legitimate business interest."209 The court stated, however, that in Kansas, "the law is clear that referral sources are a legitimate interest which can be protected by a restrictive covenant even in the context of a medical practice." 210

The court held that WSS did not have a legitimate business interest in maintaining a certain size. ${ }^{211}$ It overturned the district court's decision to permit three of the plaintiff doctors to pay liquidated damages in lieu

205. Id. at *6.

206. 279 Kan. 755,112 P.3d 81 (2005).

207. Id. at 86 .

208. Id. at 91

209. Id. at $89-90$

210. Id. (citing Graham v. Cirocco, 31 Kan. App. 2d 563, 565, 69 P.3d 194, 199 (Kan. Ct. App. 2003); Weber v. Tillman, 359 Kan. 457, 913 P.2d 84, 91 (1996)).

211. See id. at 89 (noting that the "variety of legitimate business interests which have been recognized by other courts" are not related to an employer's size). 
of enforcing the noncompetition provision in their contracts. ${ }^{212}$ Only Dr. Idbeis had a liquidated damages provision in his contract. ${ }^{213}$ The court stated that the district court was required to analyze "the scope of the restriction, not the presence of a remedy," to determine whether a noncompetition covenant was injurious to the public welfare. ${ }^{214}$ The remedy, the court said, for a breach of a noncompetition covenant "is either an injunction to enforce the contract or a computation of monetary damages." 215 The district court "made no finding that the liquidated damages provision which it grafted into the contract had any relationship to actual damages," so it was in error. ${ }^{216}$

At least one author has suggested that the Idbeis court's holding was too broad and that, while referral sources may be a legitimate business interest in some cases, they are not in the context of specialty surgical practices. ${ }^{217}$ He argues a medical group has no such interest with respect to a surgeon whose referral base develops because of his individual skills and attributes rather than the goodwill of the group's practice. ${ }^{218}$ The author suggests that the court failed to give sufficient weight to this distinction between specialty surgical practices and other medical practices. ${ }^{219}$

In an unusual case, the Kansas Court of Appeals enforced a noncompetition agreement even though the patient referral arrangement it purported to protect may have violated federal law. In Caring Hearts Personal Home Services, Inc. v. Hobley, ${ }^{220}$ Caring Hearts sought to enforce noncompetition agreements with two Licensed Practical Nurses (LPNs) after the LPNs (independent contractors) terminated their relationship with Caring Hearts. ${ }^{221}$ Among other things, the LPNs claimed that a referral arrangement between them and Caring Hearts

212. Id. at $92-93$.

213. Id. at 94 .

214. See id. at 92 (noting that the enforceability of restrictive covenants does not depend on the available remedies).

215. Id

216. Id.

217. See Mike J. Wyatt, Comment, Buy Out or Get Out: Why Covenants Not to Compete in Surgeon Contracts Are Truly Bad Medicine, 45 WASHBURN L.J. 715, 716, 732 (2006) (noting that "surgical groups cannot have a legitimate business interest in their surgeons' skills . . because surgeons cannot misappropriate their skill after resignation").

218. See id. at 731 (arguing that surgical referrals are often in response to a surgeon's skill rather than a surgical group's good will).

219. See id. at 734-37 ("The court incorrectly held that the referral relationships among referring physicians and WSS's surgeons were legitimate business interests.").

220. 35 Kan. App. 2d 345, 130 P.3d 1215 (Kan. Ct. App. 2006).

221. Id. at 1218-19. 
violated the federal antikickback provisions of 42 U.S.C. $\S 1320 a-7 b .^{222}$ The court held that even if the referral arrangement violated federal Medicare laws and regulations, the noncompetition agreement was enforceable. $^{223}$ The court reasoned that " $[\mathrm{t}] \mathrm{h}$ noncompetition agreements [did] not extend only to patients referred to Caring Hearts by [the two LPNs], but to all Caring Hearts' patients they cared for during the course of their relationship with Caring Hearts."224 The court found that Caring Hearts had a protectable interest in its relationship with all the patients the LPNs treated and that a claim of illegal kickbacks regarding the referral of some of those patients was not sufficient to invalidate the noncompetition agreement. ${ }^{225}$

A noncompetition covenant will not likely be enforced if the employer does not actually compete in the geographic area its covenant purports to cover. In Mowery Clinic, L.L.C. v. Hofer, ${ }^{226}$ the court ruled that a contract provision which "unreasonably prohibits the practice of medicine without demonstrating an unfair effect upon a former employer's legitimate business interests cannot be enforced as written" and "[ $\mathrm{t}]$ he scope of the restrictive covenant must be equitably reduced." $" 27$ The defendant physician left the Mowery Clinic to work for a Department of Veterans Affairs (VA) clinic in the geographic area set out in the covenant, which included the Salina area. ${ }^{228}$ The court found that, absent evidence that the VA clinic competed with the Mowery Clinic for patients in the Salina area, the Mowery Clinic had no legitimate business interest in preventing the physician from working at the VA. ${ }^{229}$ The noncompetition provision could not be read to prohibit her employment there. ${ }^{230}$

222. Id. at 1220 .

223. See id. at 1220,1223 ("There is no evidence that enforcement of the noncompete agreement is injurious to the public welfare.").

224. Id. at 1221.

225. Id.

226. No. 94,103, 2005 WL 3098729 (Kan. Ct. App. Nov. 18, 2005).

227. Id. at *2.

228. See id. at *1 (discussing the agreement and Mowery Clinic's argument that the defendant was prevented from working with the Salina Community Clinic, which was administered by the Department of Veterans' Affairs).

229. See id. at $* 2$ (affirming the district court in refusing to enforce the agreement and stating that there was no evidence the employment with the VA Clinic was an actual competition for patients in the Salina area).

230. See id. ("[T]he spirit of the noncompetition covenant did not encompass Dr. Hofer's work at the VA Clinic."). 
In Graham v. Cirocco, ${ }^{231}$ the Kansas Court of Appeals upheld a 150mile restriction in a nonsolicitation covenant, but struck down as overbroad a noncompetition covenant which prevented a colorectal surgeon from practicing in a geographic area that stretched from Leavenworth on the north, twenty-five miles beyond Olathe on the south, Lawrence on the west, and Blue Springs, Missouri on the east (effectively the entire Kansas City metropolitan area). ${ }^{232}$ Evidence was presented in the case that the covenant's restrictions left the Kansas City area with a dangerous ratio of one colorectal surgeon for 700,000 patients. $^{233}$ The court concluded that this evidence established that the covenant threatened the public's welfare by creating a shortage of physicians in a medically necessary specialty. ${ }^{234}$

The case of Allen, Gibbs \& Houlik, L.C. v. Ristow, ${ }^{235}$ reminds us that not every type of job is appropriate for a noncompete covenant. In Ristow, an accounting firm sought to enforce a noncompetition covenant with one of its supervisors. ${ }^{236}$ At the time of her termination, the supervisor's responsibilities included administering various employee benefit plans and supervising three teams of administrators. ${ }^{237}$ The court found no evidence in the record that the supervisor had a special relationship with any clients, that she conveyed any trade secrets that were the property of her employer, or that she received any specialized training or performed unique services. ${ }^{238}$ The periodic training she did receive kept her up to date in her field of tax regulation of employee benefit groups and was not sufficient to establish a legitimate business interest that the accounting firm could protect with a covenant. ${ }^{239}$ The court affirmed that employees must necessarily take knowledge with them when they change jobs. ${ }^{240}$

\footnotetext{
231. 31 Kan. App. 2d 563, 69 P.3d 194 (Kan. Ct. App. 2003).

232. Id. at $197,200$.

233. Id. at 200 .

234. Id.

235. 32 Kan. App. 2d 1051, 94 P.3d 724 (Kan. Ct. App. 2004).

236. Id at 725 .

237. Id.

238. See id. at 728-29 (stating that fact stipulations showed no special relationship or conveyance of trade secrets and that the training and duties were not unique).

239. See id. at 729 (stating that the training "did not rise to the level of legitimate business interest").

240. See id. at $728-29$ (stating that, under the circumstances, there was no legitimate business interest).
} 


\section{B. Oral Covenants Not to Compete}

Federal courts in Kansas have found that oral noncompetition agreements are not per se invalid. ${ }^{241}$ They are, however, subject to the statute of frauds. ${ }^{242}$

\section{Restraints on Trade Generally}

The Kansas Supreme Court has stated that it will treat any contract that requires a former employee to compensate a former employer as a restraint on competition and will apply the four-factor reasonableness test applied to covenants not to compete. ${ }^{243}$ In Varney Business Services, Inc. v. Pottroff, an agreement between an accountant and his accounting firm provided that if the accountant left the firm, he would compensate the firm for clients to which he provided services for the subsequent five years. $^{244}$ The agreement provided a payment schedule (declining percentage of revenue) for the five-year period. ${ }^{245}$ The court ruled that this type of provision is "not immune to review for reasonableness" and should be analyzed under the same test as is used for covenants not to compete. $^{246}$ However, the court did not actually apply the four-factor test, but instead stated: "Absent fraud or overreaching, however, the contracts will be enforced according to their terms." 247 It held that the provision at issue was reasonable and should be enforced. ${ }^{248}$

\section{CONFIDENTIALITY AgREEMENTS}

\section{A. Settlement Agreements}

Kansas courts will not enforce an otherwise valid settlement agreement to the extent it prevents a former employee from

241. Bradbury Co. v. Teissier-Ducros, No. 03-1391-WEB, 2004 WL 3059542, at*14 (D. Kan. Dec. 29, 2004) (citing Fireworks Spectacular, Inc. v. Premier Pyrotechnics, Inc., 86 F. Supp. 2d 1102 (D. Kan. 2000)).

242. See id. at *15 (applying the statute of frauds to the agreement).

243. See Varney Bus. Servs., Inc. v. Pottroff, 275 Kan. 20, 36, 37, 59 P.3d 1003, 1016, 1017 (2002) (stating that "provisions in which former employees are required to compensate former employers serve the same purpose as covenants not to compete" and are subject to the four-factor test).

244. Id. at 1009.

245. Id.

246. Id. at 1017.

247. Id.

248. Id. 
"disseminating even nonconfidential, truthful information when called upon to do so in connection with a claim against [a] former employer."249 In Farmers Group Inc. v. Lee, Lee, a former employee, sued his thenemployer, Farmers, and ultimately signed a settlement agreement that required Lee to "“not disclose and ... do everything possible to maintain in confidence... the facts and circumstances of any alleged discrimination, defamation, harassment, breach of contract, tort or violation of any law by Farmers against Lee or any agent or employee of Farmers.",250 Later, when Lee was asked to testify as an expert in another case brought against Farmers, Farmers sought to enforce the settlement agreement and prevent Lee from testifying. ${ }^{251}$ The court rejected Farmers' position and upheld the district court's ruling permitting Lee to participate in the litigation against Farmers. ${ }^{252}$ The court reasoned that allowing employers to prevent a former employee from disseminating nonconfidential, truthful information violated Kansas public policy. ${ }^{253}$

\section{B. Trade Secrets}

In a case involving tortious interference with nondisclosure contracts, one federal court found that information about the identities, roles, strengths, and weaknesses of employees was not a trade secret under Kansas law. ${ }^{254}$ In a case involving an alleged noncompetition agreement with a former employee, customer lists and notes constituted trade secrets under the Kansas Uniform Trade Secrets Act, ${ }^{255}$ because they contained valuable information not generally known or readily ascertainable by persons in the industry, a great amount of effort and expense was expended to develop the information, the information could not be duplicated without expending a similar amount of effort and expense, and the secrecy of the information was maintained.

249. Farmers Group, Inc. v. Lee, 29 Kan. App. 2d 382, 388-90, 28 P.3d 413, 419-20 (Kan. Ct. App. 2001).

250. Id. at 415-16.

251. See id. at 416-17 (explaining that Farmers appealed from a trial court's modification of a previously imposed injunction that had prohibited Lee from testifying against Farmers).

252. Id. at $417-20$.

253. Id. at $419-20$.

254. Bradbury Co. v. Teissier-Ducros, 413 F. Supp. 2d 1209, 1226 (D. Kan. 2006).

255. KAN. STAT. ANN. $\S \S 60-3320$ to -3330 (2006). 


\section{ARbitration AgreEMENTS}

A. State Courts: Anderson v. Dillard's, Inc.

Both the Kansas Court of Appeals and the Kansas Supreme Court examined and ruled on a Dillard's Inc. arbitration provision, which purported to cover employment claims, in Anderson v. Dillards, Inc. ${ }^{256}$ Although the Kansas Supreme Court reversed the holding of the Kansas Court of Appeals, ${ }^{257}$ both cases are instructive.

Dillard's terminated its part-time security guard, Anderson, allegedly for taking store merchandise without paying for it. ${ }^{258}$ Anderson alleged that Dillard's then called his full-time employer (Lenexa Fire Department) and another part-time employer (Spring Hill Police Department) and reported he had been arrested for shoplifting. ${ }^{259}$ Subsequently, the fire department terminated him, and the police department suspended him. ${ }^{260}$ Anderson sued for defamation, invasion of privacy, and tortious interference. ${ }^{261}$ Dillard's moved to compel arbitration. $^{262}$

While employed, Anderson signed an acknowledgment and receipt of rules for arbitration that required him to submit covered claims to arbitration. ${ }^{263}$ The acknowledgment specifically stated that:

"This Agreement does not waive anyone's substantive legal rights, nor does this Agreement create or destroy any rights. It merely changes the forum where the dispute is resolved and the procedures to be followed. Arbitration does not prevent an associate from filing a charge with an administrative agency like the Equal Employment Opportunity
Commission."264

The acknowledgment further stated that employees were deemed to have agreed to the arbitration rules by accepting employment or continuing

256. 283 Kan. 432, 153 P.3d 550 (2007), rev'g, No. 94,334, 2006 WL 1520541 (Kan. Ct. App. June 2, 2006).

257. Id. at 555 .

258. See id. at 552 (reciting the facts of the case).

259. Id.

260. Id. at 553 .

261. Id.

262. Id.

263. Id. at 552 .

264. Id. 
employment with Dillard's. ${ }^{265}$ The arbitration rules purported to cover claims "resulting from [an employee's] termination of employment." 266

The trial court refused to compel arbitration and ruled that Anderson's claims did not arise out of his employment. ${ }^{267}$ On appeal, Anderson sought to uphold the district court's finding, but also challenged the court's jurisdiction based on the Kansas Uniform Arbitration Act (KUAA). ${ }^{268}$ The Kansas Court of Appeals exercised jurisdiction. In doing so, it found that, while the KUAA invalidates arbitration agreements for future claims between employers and employees and for future tort claims, Dillard's could enforce its agreement under the Federal Arbitration Act (FAA), ${ }^{269}$ which preempts conflicting state laws. ${ }^{270}$ On the merits, the court held that Anderson's claims arose out of his employment with Dillard's and were, therefore, covered by the arbitration agreement. ${ }^{271}$

The Kansas Supreme Court found jurisdiction was proper, ${ }^{272}$ however, it reversed the court's order compelling arbitration. ${ }^{273}$ The Kansas Supreme Court found that the agreement covered claims "resulting from" termination, not "arising out of" termination. ${ }^{274}$ It reasoned that the language "results from" requires a cause and effect analysis. ${ }^{275}$ The Kansas Supreme Court explained that "Dillard's did not have a duty to inform Anderson's other employers that Anderson had been terminated from his employment, so Anderson's termination from Dillard's did not require" Dillard's to contact his other employers. ${ }^{276}$ Thus, the court held, Anderson's termination did not cause the actions that Anderson alleged as the basis for his claims, and his claims did not "result from" his termination. ${ }^{277}$ It found the Kansas Court of Appeals' decision "improperly interpreted the terms of the arbitration agreement to

265. Id.

266. Id. at 554 (emphasis removed).

267. Anderson v. Dillard's, Inc., No. 94,334, 2006 WL 1520541, at *1-*2 (Kan. Ct. App. June 2, 2006), rev'd, 283 Kan. 432, 153 P.3d 550 (2007).

268. KAN. STAT. ANN. $\S \S 5-401$ to -422 (2006).

269. 9 U.S.C $\S \S 1-16,201-208,301-307$ (2000).

270. Anderson, 2006 WL 1520541, at *2 (citing Skewes v. Shearson Lehman Bros., 250 Kan. 574,829 P.2d 874 (1992)).

271. Id.

272. Anderson, 153 P.3d at 553. The Supreme Court did not, however, speak to the appellate court's conclusion that the FAA preempts conflicting provisions of the KUAA.

273. Id. at 555 .

274. Id. at 554 .

275. Id.

276. Id.

277. Id. 
include claims arising out of employment with Dillard's rather than those resulting from the termination of employment. ${ }^{, 278}$

\section{B. Federal Court Cases}

Federal courts in Kansas have repeatedly examined the enforceability of arbitration agreements in the employment context. A summary of some of these cases follows. One court held that an employer may not force an employee to arbitrate a claim under a veterans' rights act.

\section{Enforced Agreements}

A federal district court enforced an arbitration clause set forth in a separation agreement in Lynn v. General Electric Co. ${ }^{279}$ In Lynn, employees brought claims under the Fair Labor Standards Act (FLSA), ${ }^{280}$ and General Electric Transportation Systems (GETS) moved to compel arbitration as to one plaintiff. ${ }^{281}$ GETS had terminated the plaintiff and provided him with severance pay in return for a waiver and release of claims. ${ }^{282}$ GETS did not argue that Lynn waived his FLSA claim, but rather that the claim had to be submitted to binding arbitration. ${ }^{283}$ The separation agreement stated that "[Employee] agree[s] to submit to final and binding arbitration. 284 The agreement gave the plaintiff twenty-one days to review the agreement and stated that he could revoke it within seven days after he signed it. The plaintiff "accepted four weeks of severance pay, and he did not exercise his right to revoke the separation agreement." 285 The plaintiff initialed each page of the agreement and placed an " $x$ " by a paragraph that stated he read the agreement and was advised to consult an attorney. ${ }^{286}$ The GETS Resolved Procedure Handbook was not attached to the separation agreement; however, at the start of his employment, the plaintiff signed a form indicating he received and reviewed a copy of the GETS dispute resolution procedure guidelines and a cover page indicating he read and received the GETS

278. Id. at 554-55.

279. 407 F. Supp. 2d 1257 (D. Kan. 2006).

280. 29 U.S.C. $\S \S 201-219$ (2000).

281. Lynn, 407 F. Supp. 2d at 1260.

282. Id. at 1257 .

283. Id. at 1260 .

284. Id.

285. Id.

286. Id. 
handbook for dispute resolution (all these documents were located on the company's internal internet site). ${ }^{287}$

The court rejected the plaintiff's argument that the arbitration clause was invalid because the handbook was not attached to the agreement. ${ }^{288}$ Applying Pennsylvania law, which the court stated was consistent with federal law, the court enforced the agreement. ${ }^{289}$ The court reasoned that "the separation agreement clearly stated [that plaintiff] agreed to submit to final and binding arbitration.",290 The plaintiff read the provision and realized the handbook was not attached, but he made no attempt to obtain a copy. The plaintiff acknowledged he had received, reviewed, and agreed to the dispute guidelines and they were available on the GETS website. He had twenty-one days to review the separation agreement and consult with counsel and could revoke it within seven days. The plaintiff had "more than ample opportunity to review and understand the implications of the arbitration clause within the separation agreement."

In an earlier decision in the same case, the court refused to stay the litigation pending mediation of the dispute between GETS and three of the plaintiffs. ${ }^{292}$ GETS argued that its dispute resolution program required these plaintiffs to submit their claim to mediation. ${ }^{293}$ These plaintiffs were already employed at the time GETS implemented its dispute resolution program. ${ }^{294}$ GETS argued it notified the plaintiffs it was implementing the program because it sent a letter to all employees' homes, placed an article in the company newsletter, provided the dispute resolution guidelines and other information on the program on the intracompany website, and sent an email to all employees announcing the guidelines and providing a link to the website. ${ }^{295}$ The plaintiffs maintained that they never received the letter, did not read the newsletter article, did not access information regarding the program on the intracompany website, and did not read the email. ${ }^{296}$ The court first found that Kansas law, not the FAA, governed whether there was an agreement to mediate. ${ }^{297}$ The court found that arbitration and mediation

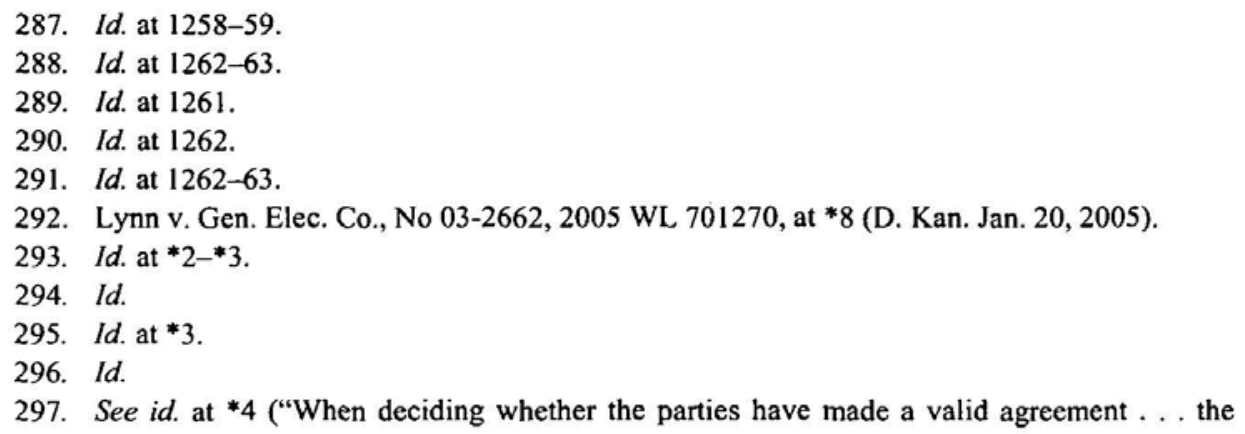


are completely different processes and that treating a mediation like an arbitration did not serve Congress's intended purposes. ${ }^{298}$ Thus, the court held that the term "arbitration" in the FAA does not include mediation, and Kansas common law governing formation of contracts applied to determine whether the parties had agreed to mediate. ${ }^{299}$

Applying Kansas law, the court found there was no agreement to mediate. The court found that GETS failed to present evidence that it actually made any of the plaintiffs aware of the new requirement to mediate. ${ }^{300}$ There was no signed acknowledgement form, nor did GETS demonstrate that the plaintiffs actually opened the emails sent to them or accessed the applicable portion of the website. Merely disseminating the information was insufficient to establish a binding agreement. ${ }^{301}$

The court enforced an arbitration provision in a handbook when the handbook specifically referenced the arbitration policies and indicated that the policies created a contract between the parties. ${ }^{302}$ In Lorntzen $v$. Swift Transportation, Inc., the court recognized that "when an arbitration clause is a part of an employee handbook that also contains statements advising the employee that the handbook does not create a contract, and that the employer reserves the right to rescind or revise any portion of the handbook, the agreement to arbitrate is unenforceable." 303 However, the court distinguished the case from others refusing to compel arbitration, because the applicable handbook specifically distinguished between the policies that created a contract and the policies for which the defendant unilaterally reserved the right to rescind or revise. ${ }^{304}$

In Lorntzen, the court also held that a safety compliance assistant for Swift Transportation was not a transportation worker so as to be covered by the FAA provisions exempting transportation workers from its provisions. $^{305}$ The plaintiff fell into the category of workers who "work[] in a transportation industry but [are] in a distant relationship to other workers who are transportation workers. Examples include security guards at airports and train stations or warehouse workers who construct

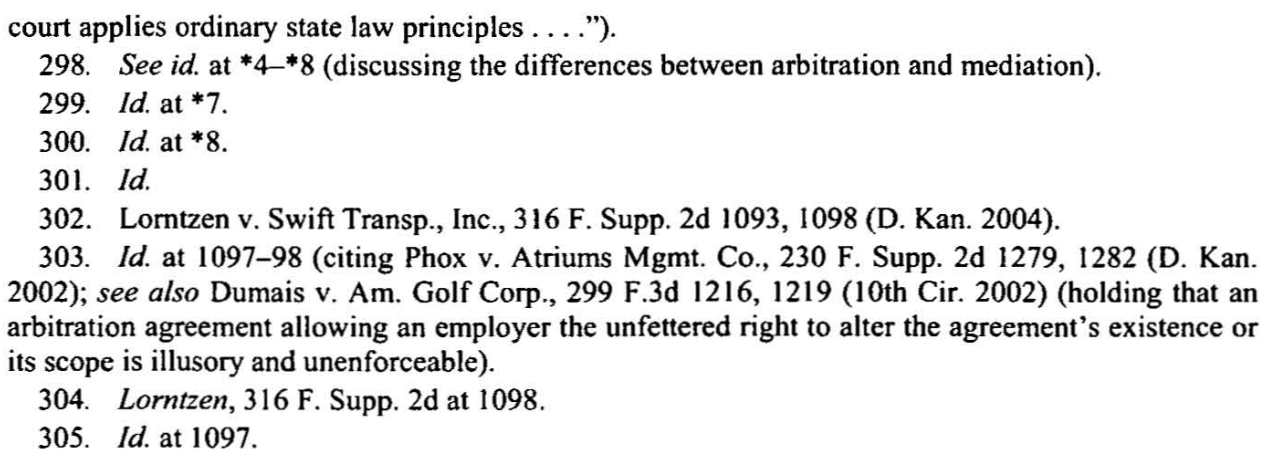


and package goods that eventually travel interstate."306 "Plaintiff's duties were more akin to those [of] employees who [support] . . . the transportation industry, but who are not themselves transportation workers." ${ }^{307}$ Thus, the plaintiff was not an exempt transportation worker. $^{308}$

An agreement to arbitrate was not illusory when "the portion of the receipt and acknowledgement that [gave the employer] the right to ... add or delete at any time any benefits ... specifically exempt[ed] the dispute resolution policy and agreement to arbitrate.",309 In Gratzer v. Yellow Corp., the acknowledgement was clear that the dispute resolution policy and "the agreement to arbitrate [could be] changed only following notice to employees." ${ }^{310}$ Because the employer was required to provide notice before changing the policy or the arbitration agreement, and because the policy and the arbitration agreement were conditions of employment, the court found that the arbitration agreement had mutuality of obligation and was not illusory. ${ }^{311}$

The defendant's arbitration agreement was enforceable despite the fact that it required the employee bringing the claim to pay one half of the arbitration fees and costs. ${ }^{312}$ The court found that the plaintiff bore the burden of showing the likelihood of incurring costs making the arbitration prohibitively expensive. ${ }^{313}$ The plaintiff did not present any evidence regarding the potential cost of the arbitration or indicating arbitration would be so expensive as to deter her from vindicating her statutory rights. ${ }^{314}$ The court further indicated that even if she presented this evidence, it would be inclined to invoke the savings clause in the

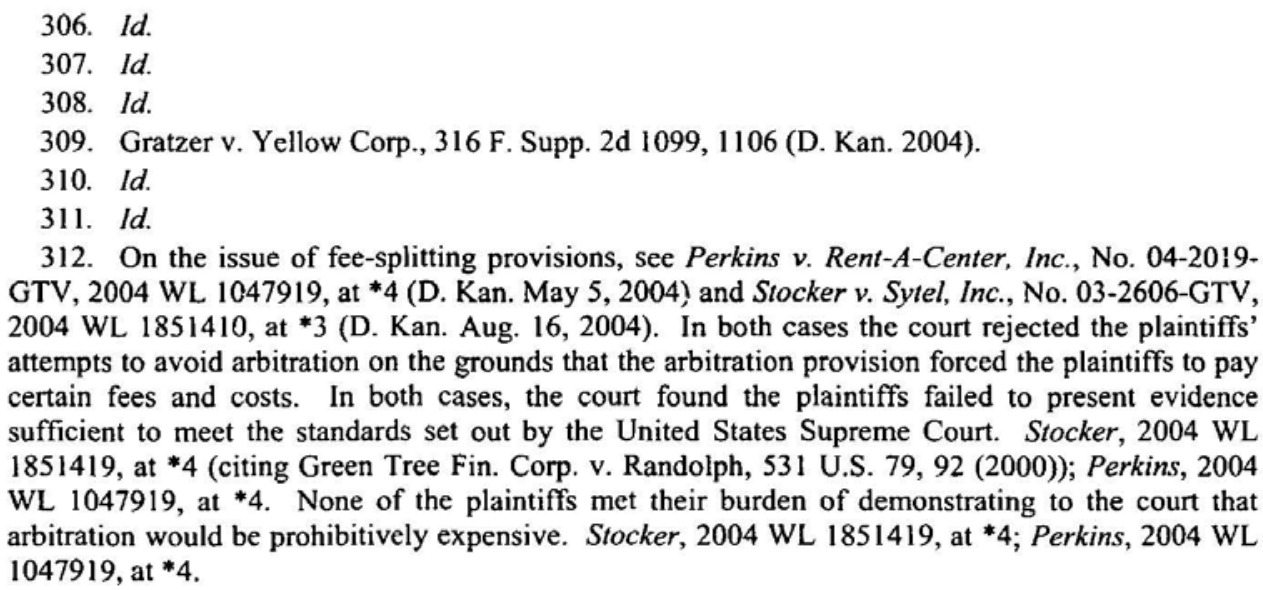

312. On the issue of fee-splitting provisions, see Perkins v. Rent-A-Center, Inc., No. 04-2019. GTV, 2004 WL 1047919, at *4 (D. Kan. May 5, 2004) and Stocker v. Sytel, Inc., No. 03-2606-GTV, 2004 WL 1851410, at *3 (D. Kan. Aug. 16, 2004). In both cases the court rejected the plaintiffs' attempts to avoid arbitration on the grounds that the arbitration provision forced the plaintiffs to pay certain fees and costs. In both cases, the court found the plaintiffs failed to present evidence sufficient to meet the standards set out by the United States Supreme Court. Stocker, 2004 WL 1851419 , at *4 (citing Green Tree Fin. Corp. v. Randolph, 531 U.S. 79, 92 (2000)); Perkins, 2004 WL 1047919 , at $* 4$. None of the plaintiffs met their burden of demonstrating to the court that arbitration would be prohibitively expensive. Stocker, 2004 WL 1851419, at *4; Perkins, 2004 WL 1047919 , at *4.

313. Gratzer, 316 F. Supp. 2d at 1104-05.

314. Id. at 1105 . 
arbitration agreement, which would strike the fee-splitting provision and cause the employer to pay the arbitration costs. ${ }^{315}$

The plaintiff's argument that her continued at-will employment was insufficient consideration to support an arbitration agreement was rejected in Felling $v$. Hobby Lobby, Inc. ${ }^{316}$ The court stated that "an employer's specific promise to continue to employ an at-will employee may provide valid consideration for an employee's promise to forgo certain rights." 317 In any event, because the employer had the obligation under the agreement to submit its claims against the plaintiff to arbitration, the agreement was valid. "Mutual promises to arbitrate serve as sufficient consideration." 318

The Felling court also rejected the plaintiff's contention that there was no meeting of the minds regarding an agreement to arbitrate. Applying Kansas law, ${ }^{319}$ the court said there needed to be a "fair understanding between the parties which normally accompanies mutual consent and the evidence must show with reasonable definiteness that the minds of the parties met upon the same manner and agreed upon the terms of the contract." "320 The court found a meeting of the minds because the plaintiff signed a memorandum that expressly stated the plaintiff's continued employment constituted acceptance of the agreement to arbitrate and of the arbitration procedures, it stated the plaintiff's substantive rights would be resolved in arbitration rather than court, and it specifically bound the employer to the agreement to arbitrate and to the arbitration procedures. ${ }^{321}$

315. Id. The arbitration agreement stated the arbitrator's fees would be split equally "unless other express statutory provisions or controlling case law' conflict with this allocation and require the payment of costs and fees by [the employer]. If such a conflict exists, the costs of arbitration and the arbitration fees will be paid by [the employer]." Id. at 1102.

316. No. 04-2374-GTV, 2005 WL 928641 (D. Kan. Apr. 19, 2005).

317. Id. at *4 (citing Durkin v. Cigna Prop. \& Cas. Corp., 942 F. Supp. 481, 483, 488 (D. Kan. 1996).

318. Id.

319. When ruling on the enforceability of an arbitration agreement, courts generally apply ordinary state law rules governing contract formation. See id. at *2 (noting that "courts generally apply ordinary state law principles that govern the formation of contracts" when determining whether to enforce an arbitration clause); see also Clary v. The Stanley Works, No. 03-1168-JTM, 2003 WL 21728865 , at *2 (D. Kan. July 24, 2003) (“[T] principles to determine whether the parties actually agreed to arbitrate.").

320. Felling, 2005 WL 928641, at *3 (quoting Steele v. Harrison, 552 P.2d 957, 962 (Kan. 1976)).

321. Id. 


\section{No Agreement Found}

The court refused to find an agreement to arbitrate when references to arbitration were included in an employee handbook that the employer retained the right to alter or modify at any time without notice. ${ }^{322}$ In Barnes $v$. Securitas Security Systems, the employer gave the plaintiff a handbook and a copy of a brochure setting out the company's arbitration "program." The plaintiff signed separate forms acknowledging that she had received the handbook and the arbitration program brochure, and acknowledging that the arbitration program was a condition of employment. ${ }^{323}$ The handbook, however, also stated that the company could "'modify, supplement, terminate or revise the provisions of the Handbook, other than the at will requirement[,] at any time."'324

Relying on Dumais v. American Golf Corp. ${ }^{325}$ the court found that the agreement to arbitrate was illusory because the defendant retained the right to modify or terminate it at any time. ${ }^{326}$ The defendant argued the agreement was not illusory because the handbook was distinct from the arbitration program brochure. The court rejected this argument because the handbook expressly governed the terms and conditions of employment, contained an arbitration agreement, and incorporated the arbitration brochure. ${ }^{327}$ The court also rejected the defendant's argument that the agreement was not illusory because the defendant was required to give notice to employees if it altered conditions of their employment. The defendant cited cases finding that an arbitration agreement is not illusory if the employer "retains the right to alter or amend only after putting the change in writing, providing a copy to employees and allowing employees to accept the change by continuing employment." ${ }^{228}$ The court easily distinguished these cases by pointing out that the defendant's handbook did not require it to provide prospective notice of any changes, and in fact, there was some evidence changes could be made without any notice. ${ }^{329}$

322. Barnes v. Securitas Sec. Sys. USA, Inc., No. 05-2264-JWL, 2006 WL 42233, at *5 (D. Kan. Jan. 6, 2006).

323. Id. at $* 1-* 2$.

324. Id. at *2.

325. 299 F.3d 1216 (10th Cir. 2002).

326. Barnes, 2006 WL 42233 , at *3.

327. Id. at $* 4$.

328. Id.

329. Id. 
In Phox $v$. Atriums Management Co. ${ }^{330}$ the defendant employer argued that its employee handbook established an agreement to arbitrate the plaintiff's discrimination claims. The plaintiff argued, and the court agreed, that the handbook did not bind the defendant, so any agreement based on it was illusory. ${ }^{331}$ The court found that various disclaimers in the handbook prevented the handbook from creating an agreement. Among other things, the handbook stated that "nothing in this manual should be construed as an express or implied contract of employment for any length" and that policies in it "do not create express or implied ... contractual obligations of any kind." 332 The defendant reserved the right in the handbook to revise or rescind the policies in its "sole and absolute discretion" and the policies could be "amended or cancelled at any time" at the defendant's sole discretion. ${ }^{333}$ The defendant argued there was a separate binding agreement to arbitrate and that either (1) the promise to arbitrate or (2) the promise of employment served as consideration for the agreement. The court rejected both arguments. ${ }^{334}$ The promise to arbitrate was illusory because the defendant reserved the unilateral right to revise or cancel the arbitration clause before the plaintiff filed a claim. The promise of employment was illusory because the plaintiff was employed at will and could be terminated at any time. Finally, the court found that there was no meeting of the minds on the alleged arbitration agreement because the plaintiff did not sign or initial the page of the handbook that contained the arbitration clause. ${ }^{335}$

\section{USERRA Claims}

While arbitration agreements may generally be enforced in the employment context, at least one court has held that a USERRA claim is not subject to arbitration. While the Supreme Court of the United States has found that other employment statutes do not supersede arbitration agreements, a federal court in Kansas has found that the Uniformed Services Employment and Reemployment Rights Act (USERRA) ${ }^{336}$ does. ${ }^{337}$ At the outset, the court recognized that whether the USERRA

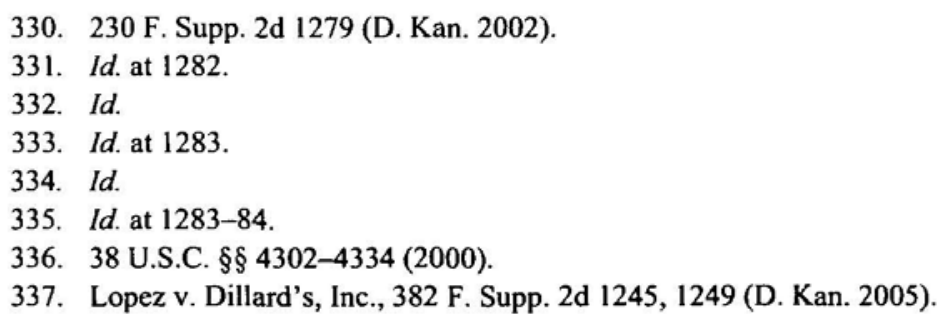


renders unenforceable an otherwise valid agreement to arbitrate employment disputes was a matter of first impression in the Tenth Circuit and noted that only one other reported case addressing this question existed ${ }^{338}$ In ruling, the court relied on $\S 4302$ (b) of the USERRA, which states that the statute supersedes any contract or agreement "that reduces, limits, or eliminates in any manner any right or benefit provided by this chapter, including the establishment of additional prerequisites to the exercise of any such right or the receipt of any such benefit." ${ }^{339}$ The court found that the arbitration agreement did not require the plaintiff to give up any substantive rights by arbitrating her claim, because the arbitrator was to apply the same substantive law, and was empowered to grant the same relief, as the court could. ${ }^{340}$ However, the court held that because the arbitration agreement mandated that the plaintiff seek relief in an arbitral forum, and this forum was not addressed in the USERRA, the agreement stood as an additional prerequisite to the exercise of the plaintiff's rights and the receipt of benefits she might be entitled to under the act. ${ }^{341}$ Thus, the court held the plain language of 38 U.S.C. $\S 4302$ requires that the USERRA supersede the arbitration agreement. ${ }^{342}$

\section{WAge PAYMENT}

\section{A. Undocumented Workers}

The Kansas Supreme Court recently held that the Immigration Reform and Control Act of 1986 (IRCA) ${ }^{343}$ does not preempt the Kansas Wage Payment Act (KWPA) ${ }^{344}$ to the extent the KWPA requires an employer pay an undocumented worker for earned wages. ${ }^{345}$ In Coma Corp. v. Kansas Department of Labor, the employer sought to overturn the Kansas Department of Labor's (KDOL) order awarding wages, interest, and a penalty to a former employee. There was no dispute that the employee was an undocumented worker not legally permitted to

\footnotetext{
338. Id. at 1246 (citing Garrett v. Circuit City Stores, Inc., 338 F. Supp. 2d 717, 722 (N.D. Tex. 2004) (finding that USERRA claims are not subject to an otherwise valid arbitration agreement)).

339. Id. at 1247.

340. Id. at $1247-48$.

341. Id. at 1248.

342. Id.

343. 8 U.S.C. $\S 1324 a(2000)$.

344. KAN. STAT. ANN. § 44-313 (2006).

345. Coma Corp. v. Kan. Dep't of Labor, No. 95,537, 2007 WL 858869, at *8 (Kan. Mar. 23, 2007).
} 
work in the United States. The employer argued that the employee's employment contract was illegal and unenforceable because he was an illegal alien and that federal immigration law (namely 8 U.S.C. $\S 1324 \mathrm{a}$ which makes employment of unauthorized aliens illegal) preempts the KWPA. ${ }^{346}$

The court rejected the preemption argument, reasoning that the KWPA actually furthers the goals of the IRCA which requires that employers discharge a worker upon discovering the worker's undocumented alien status.

"If employers know that they will not only be subject to civil penalties, 8 U.S.C. $\S 1324 \mathrm{a}(\mathrm{e})(4)(\mathrm{A})$, and criminal prosecution, 8 U.S.C. $\S$ $1324 \mathrm{a}(\mathrm{f})(\mathrm{l})$, when they hire illegal aliens, but they will also be required to pay them at the same rates as legal workers for work actually performed, there are virtually no incentives left for an employer to hire an undocumented alien in the first instance. Whatever benefit an employer might have gained by paying less than the minimum wage is eliminated and the employer's incentive would be to investigate and obtain proper documentation from each of his workers."

The court further rejected the employer's argument that the employee was not entitled to the KWPA's statutory penalty for willful failure to pay wages. ${ }^{348}$ "[W]hen a statute is plain and unambiguous, the court must give effect to the intention of the legislature as expressed rather than determine what the law should or should not be. The statute, K.S.A. 44-315(b), does not carve out any 'illegal alien' exception.",349

\section{B. Vacation Pay}

In A.O. Smith Corp. v. Kansas Department of Human Resources, ${ }^{350}$ the Kansas Court of Appeals found that employees had been "discharged" within the meaning of the KWPA when their employer sold its business even though the employees retained their jobs with identical compensation and benefits with the purchasing company. ${ }^{351}$ The court reasoned that the employees clearly were terminated by their former employer and that to hold otherwise would create an unintended loophole in the statute by allowing employers to sell existing businesses and

346. Id. at *3.

347. Id. at *9 (citing Flores v. Amigon, 233 F. Supp. 2d 462, 464 (E.D.N.Y. 2002)).

348. Id. at *16.

349. Id. (citation omitted).

350. 36 Kan. App. 2d 530, 144 P.3d 760 (Kan. Ct. App. 2005).

351. Id. at 767 . 
escape liability for wages owed to employees at the time of the sale. ${ }^{352}$ The court upheld the Kansas Department of Human Resource's (KDHR) final action in the case and ruled that the agency's interpretation of the KWPA was entitled to deference when the agency provided a rational basis for its interpretation. ${ }^{353}$

The court also examined whether, prior to the sale, the selling employer (A.O. Smith) had effectuated a change in the vacation policy from an accrual policy to an "earn as you go" policy. ${ }^{354}$ The court ruled that no change could have occurred because the employer provided no notice of the change to its employees. ${ }^{355}$ "An employer may impose a cut in wages if the change is announced before any wages are earned." 356

Finally, the court upheld the KDHR's determination that the selling employer "willfully" withheld the accrued vacation pay, and reversed the district court's holding to the contrary. ${ }^{357}$ The court found that, even if it agreed with the district court's weighing of the equities, the district court exceeded its limited scope of judicial review of the agency's decision. ${ }^{358}$ The court found that the employer attempted to apply an interpretation inconsistent with its policy, acted unilaterally to change its policy without notifying employees, urged its purchaser not to discuss accrued vacation liability with employees, and attempted through the asset purchase agreement to avoid litigation by assuring some vacation would be earned and payable by the successor in the first year of employment. ${ }^{359}$ This constituted "substantial evidence" sufficient to support the conclusion that the employer intended to "cause harm" to the employees and, therefore, supported a finding of a willful violation. ${ }^{360}$

Relying on the reasoning of the Kansas Supreme Court in Sweet $v$. Stormont Vail Regional Medical Center ${ }^{361}$ the U.S. District Court for the District of Kansas enforced an employer's policy that decreased an employee's pay if the employee failed to provide two weeks' notice of her intent to leave employment. ${ }^{362}$ The policy stated that if the employee

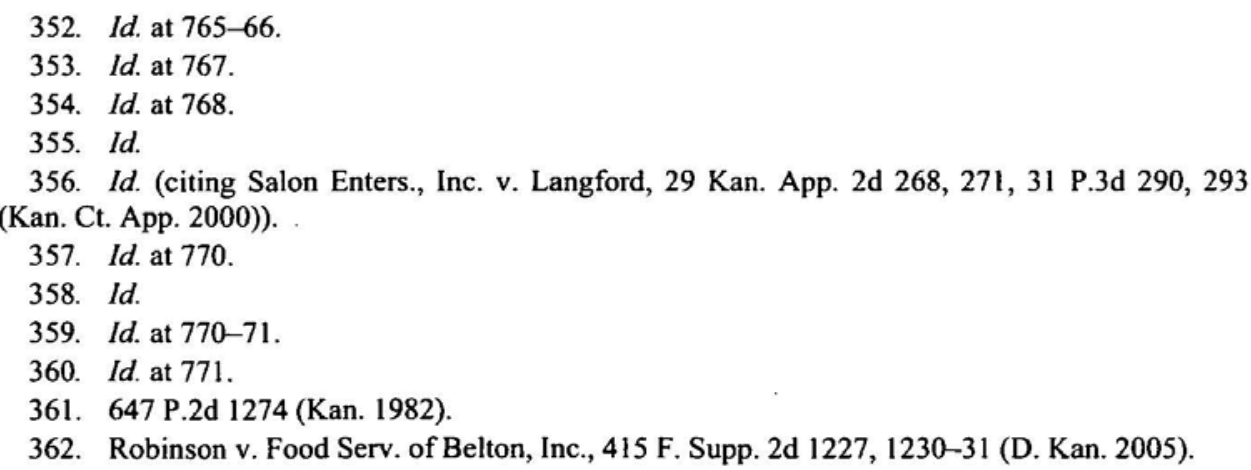


failed to provide the two weeks' notice, the employer would pay the employee the federal minimum wage rate (instead of the employee's higher hourly rate) for the last pay period the employee worked. ${ }^{363}$ The court reasoned that "neither Kansas nor federal law required [the employer] . . . pay . . . wages higher than the federal minimum wage absent [an] agreement" with the employee, so the employees "did not have an inherent right to wages higher than the federal minimum wage." 364 Thus, their right to the higher wage stemmed from their employment contract. ${ }^{365}$ "Under the rationale of Sweet, then, plaintiffs (assuming they were aware of the notice policy) did not earn wages at their regular rate of pay for the final pay period unless they satisfied the condition precedent of the contract-providing two weeks' notice prior to resigning their employment."

\section{Oral Withholding Agreements Void}

An oral agreement to withhold wages is void. In Beckman v. Kansas Department of Human Resources, ${ }^{367}$ the court held that an oral agreement to withhold an employee's wages in excess of $\$ 800$ per month was clearly illegal under the KWPA. ${ }^{368}$ The Beckman court also held that the cause of action accrued when the employer failed to pay the earned wages on the regular payday and upheld the hearing officer's determination that the violation was willful because some of the money was held as "an afterthought and an excuse not to pay, contrived later with no relationship to a sincere belief . . . that the wages were rightfully withheld." 369

\section{DRUG TESTING}

The Kansas Supreme Court affirmed an employer's enforcement of its drug-testing policy in the face of a retaliatory discharge claim. In Bracken v. Dixon Industries, Inc. ${ }^{370}$ already discussed above, Dixon had a drug testing policy that required, among other things, that an employee

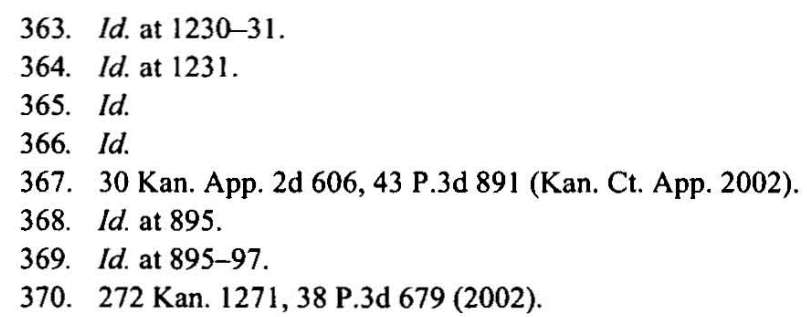


be tested when the employee was involved in an on-the-job accident or was sent to the company doctor or hospital. ${ }^{371}$ The policy stated that "any employee who tested positive or admitted being under the influence of alcohol or drugs [would be] terminated."372 Bracken, a long-term employee of eighteen years, complained of pain in her arms and hands and subsequently saw the company doctor. ${ }^{373}$ She tested positive for cannabis and admitted to Dixon that she smoked marijuana the night before. ${ }^{374}$ Dixon then terminated her. ${ }^{375}$ Bracken filed a retaliatory discharge claim against Dixon, alleging she was a good worker and had been discharged because Dixon anticipated she would file a worker's compensation claim. ${ }^{376}$ There was evidence that at least one other Dixon employee had been terminated after a positive test, and no known instances of an employee remaining employed following a positive test. ${ }^{377}$ The Court found "no inference of discriminatory intent in Dixon's actions.",378

\section{LEAVES OF ABSENCE FOR VICTIMS OF DOMESTIC ABUSE AND SeXual AsSault}

The 2006 legislature enacted a statute requiring that employers give employees who are victims of domestic violence or sexual assault time off from work for certain specified reasons. ${ }^{379}$ This statute was part of a larger bill dealing with address confidentiality for victims of domestic violence, sexual assault, trafficking, or stalking, and authorizing the Secretary of State to perform certain functions in maintaining confidential addresses. ${ }^{380}$

For purposes of the leave of absence provision of the 2006 law, "domestic violence" means abuse as defined in section 60-3102 of the Kansas Statutes, ${ }^{381}$ and "sexual assault" means any crime defined in

371. Id. at 681 .

372. Id.

373. Id. at 1274

374. Id.

375. Id.

376. Id.

377. Id. at 1279 .

378. Id.

379. Act of May 24, 2006, ch. 213, §§ 9-10, 2006 Kan. Sess. Laws 1824, 1829-30 (codified at KAN. STAT. ANN. §§ 44-1131 to-1132 (2006)).

380. Id. $\S § 1-8$ (codified at KAN. STAT. ANN. $\S ~ 75-451$ to $-458(2006)$ ).

381. KAN. STAT. ANN. § 44-1131(a). 
various criminal statutes dealing with sexual offenses. ${ }^{382}$ Neither "employer" nor "employee" is defined. Presumably courts will apply a common law definition of employee, but the lack of a definition for employer raises the question whether the statute will apply to employers with only one employee.

The law prohibits an employer from firing, discriminating, or otherwise retaliating against an employee who is a victim of domestic violence or sexual assault for taking time off work to:

(1) Obtain or attempt to obtain any relief, including ... injunctive relief to help ensure the health, safety or welfare of the victim or the victim's child or children; (2) seek medical attention for injuries caused by domestic violence or sexual assault; (3) obtain services from a domestic violence shelter, domestic violence program or rape crisis center . . . ; or (4) make court appearances in the aftermath of domestic violence or sexual assault.

The employee must "give the employer reasonable advance notice of [his or her intent] to take time off, unless such advance notice is not feasible." ${ }^{, 384}$ Within forty-eight hours of returning from the time off, the employee must provide documentation to substantiate the reason for the leave. ${ }^{385}$ The documentation may include, but is not limited to, "[a] police report indicating that the employee was a victim of domestic violence or sexual assault;" "a court order protecting or separating the employee from the perpetrator of an act or domestic violence or sexual assault, or other evidence from the court or prosecuting attorney that the employee has appeared in court;" or documentation from an appropriate professional that the employee was undergoing treatment for physical or mental injuries or abuse. ${ }^{386}$ If an unscheduled absence occurs, "the employer shall not take any action against the employee if the employee, within [forty-eight] hours after the beginning of the unscheduled absence, provides a certification to the employer in the form of any" of the documentation just listed. ${ }^{387}$ Employers are required to maintain the confidentiality of any employee seeking leave under the statute and the confidentiality of any supporting documentation the employee provides. $^{388}$ Finally, an employee may use any accrued paid leave, or if

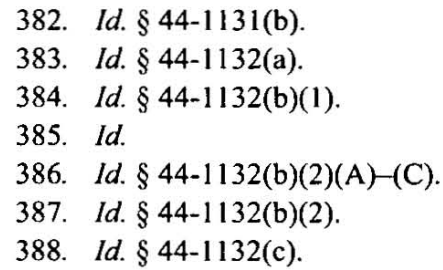


the employee has no paid leave available, unpaid leave, of up to a total of eight days per calendar year, as time off for a purpose described in the statute, unless an applicable collective bargaining agreement or other terms of employment provide for a longer period of time. ${ }^{389}$

Missing from this statute is any means of enforcement. Even assuming that employers and employees are aware of their rights and responsibilities under this leave law, what recourse does an employee have if he or she is fired in violation of the express terms of the statute? Or what if the employer fails to keep the employee's name and the reason for the leave confidential? The failure to provide for a civil cause of action with a damages remedy must have been a legislative oversight. If the legislature does not amend the statute to deal with this omission, the leave law might well be the perfect opportunity for the Kansas Supreme Court to expand the scope of the public policy wrongful discharge cause of action under Kansas law. 